Linköping University Medical Dissertation

No. 1565

\title{
Cardiac disease in pregnancy and consequences for reproductive outcomes, comorbidity and survival
}

\author{
Kristina Kernell
}

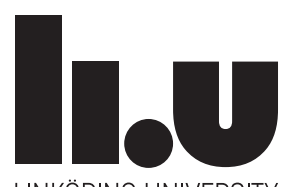

LINKÖPING UNIVERSITY

Department of Obstetrics and Gynecology Department of Clinical and Experimental Medicine

Linköping University, Linköping, Sweden Linköping 2017 
Cardiac disease in pregnancy and consequences for reproductive outcomes, comorbidity and survival

(C) Kristina Kernell

ISBN 978-91-7685-571-3

ISSN 0345-0082

Printed by LiU-tryck, Linköping, Sweden 2017 


\section{Abstract}

\section{Background}

Advances in medical treatment during the last 50 years have resulted in more individuals with congenital heart disease (CHD) and Marfan syndrome reaching childbearing age. The substantial physiological changes during pregnancy result in a high-risk situation, and pregnancy is a major concern in women with these conditions.

\section{Aims}

- To describe the socio-demographic characteristics, birth characteristics and reproductive patterns of individuals with CHD and women with Marfan syndrome.

- To investigate obstetric and neonatal outcomes in the firstborn children of individuals with CHD and women with Marfan syndrome.

- To study long-term cardiovascular outcomes after childbirth in women with Marfan syndrome.

\section{Methods}

The studies are population-based register studies. The study population in the first paper included all women born between 1973 and 1983 who were alive and resident in Sweden at the age of 13 (494 692 women, of whom 2216 were women with CHD). In the second paper, the same definition of the study population was chosen, except that it involved all men born between 1973 and 1983 (522 216 men, of whom 2689 men with CHD). The third and fourth papers involved a study population of all Swedish women born between 1973 and 1993 who were still living in Sweden at age 13. This population consisted of 1017538 women, 273 of whom had been diagnosed with Marfan syndrome.

\section{Results and conclusions}

The individuals studied were more often born preterm, and were small-for-gestational age babies. They were more likely to have been born by cesarean section. In women with CHD, these characteristics were repeated in their firstborn children. No increased risks were found in children of men with CHD or in children of women with Marfan syndrome. There was no increased risk of aortic dissection in women with Marfan syndrome during pregnancy compared to women with Marfan syndrome who did not give birth. Higher frequencies of cardiac arrhythmia and valvular heart disease were found after childbirth in women with Marfan syndrome.

Pregnancy in women with CHD is a high-risk situation associated with increased risk of adverse neonatal outcomes for the expected child. Pregnancy in women without CHD, but where the father has CHD is not so associated with increased risk of adverse obstetric or neonatal outcomes. Pregnancy in women with Marfan syndrome is not associated with adverse outcomes for the expected child. 


\section{Contents}

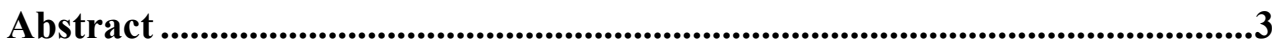

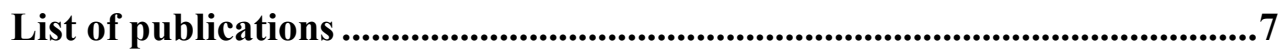

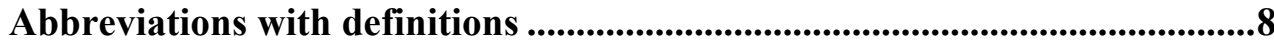

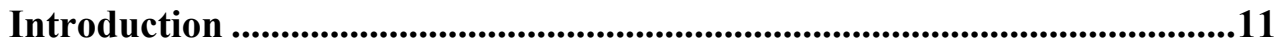

Cardiovascular physiology of pregnancy and labor.......................................11

Long-term outcomes in general after childbirth ............................................13

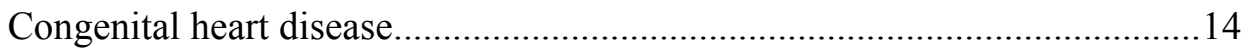

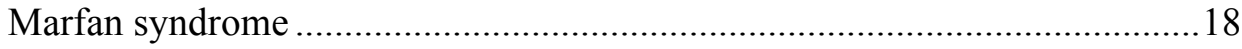

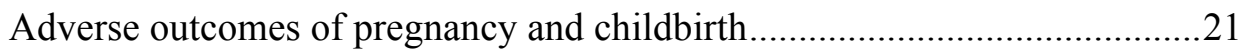

Specific background to the present studies ................................................23

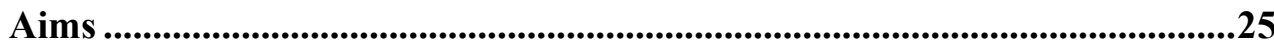

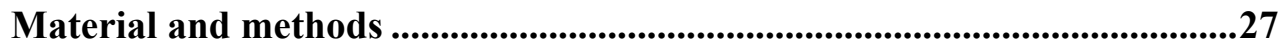

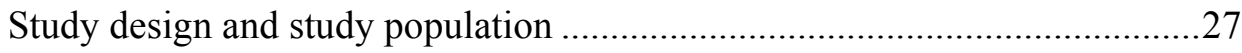

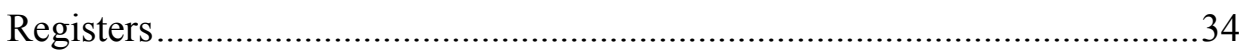

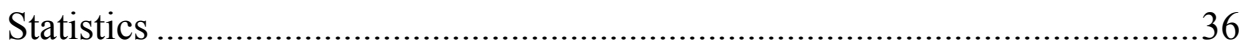

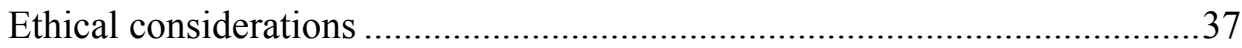

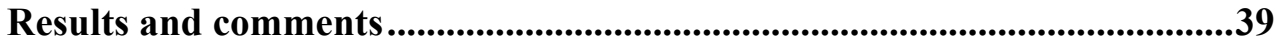

Birth characteristics of individuals with CHD ..............................................39

Specific results in Paper I: Women with CHD ..............................................39

Specific results in Paper II: Men with CHD ................................................40

Birth characteristics of women with Marfan syndrome...................................41

Specific results in Paper III: Women with Marfan syndrome ........................42

Specific results in Paper IV: Long-term cardiovascular outcomes after

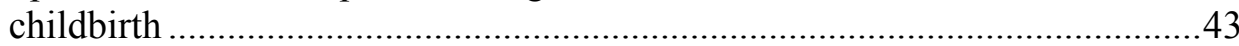

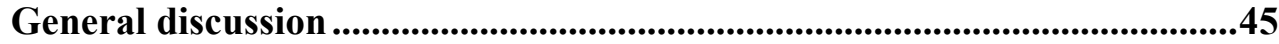

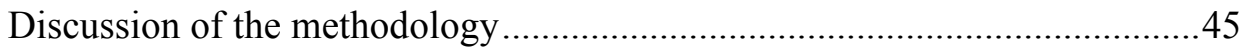

Discussion of the results ..........................................................................49

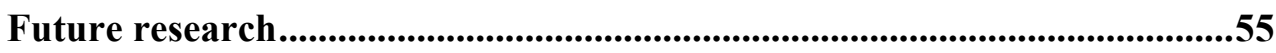

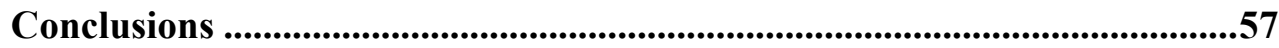

Populärvetenskaplig sammanfattning ....................................................59 


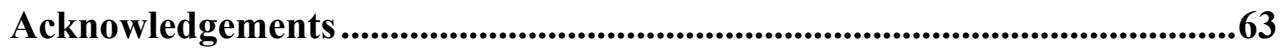

References ...................................................................................................................65

Errata.........................................................................................................................70 


\section{List of publications}

I. Josefsson A, Kernell K, Nielsen NE, Bladh M, Sydsjö G. Reproductive patterns and pregnancy outcomes in women with congenital heart disease - a Swedish population-based study. Acta Obstet Gynecol Scand. 2011 Jun;90(6):659-65.

II. Kernell K, Sydsjö G, Bladh M, Nielsen NE, Josefsson A. Congenital heart disease in men - birth characteristics and reproduction: a national cohort study. BMC Pregnancy Childbirth. 2014; 14: 187.

III. Kernell K, Sydsjö G, Bladh M, Josefsson A. Birth characteristics of women with Marfan syndrome, obstetric and neonatal outcomes of their pregnancies - a nationwide cohort and case-control study. Under review.

IV. Kernell K, Sydsjö G, Bladh M, Josefsson A. Long-term cardiovascular outcomes after pregnancy among women with Marfan syndrome. Manuscript.

The published papers are reprinted by permission of the publishers. 


\section{Abbreviations with definitions}

$A C T H$

Adrenocorticotropic hormone

A polypeptide hormone produced in response to biological stress. It stimulates the secretion of glucocorticoid steroid hormones.

$A S D$

Atrial septal defect

A congenital heart defect consisting of a defect in the wall between the heart's two upper chambers (atria).

AVSD Atrioventricular septal defect

A congenital heart defect, which involves defects of both the atrial wall and inlet ventricular wall and the presence of a common atrioventricular valve.

BMI Body mass index

A measure of the relative size of an individual, based on body weight and body height. It is calculated as body weight divided by the square of the body height $\left(\mathrm{kg} / \mathrm{m}^{2}\right)$.

CHD Congenital heart disease

Congenital malformation of a cardiovascular structure or function, which is present at birth. CHD is the most common group of congenital malformations, with an incidence of about 8 to 10 in 1000 individuals.

CI Confidence interval

Statistical term used to express the degree of uncertainty associated with a population sample. A confidence interval is an estimate of an unknown population parameter, which is likely to include the unknown population parameter within the range. The level of confidence chosen (e.g. 95\%) indicates the probability that the estimated range captures this true population parameter.

International Statistical Classification of Diseases and Related Health Problems

An international standard for classification of diseases and injuries published by the World Health Organization. 
LGA Large-for-gestational age

Children born LGA have a higher birth weight than normal for their gestational age. The definition used in this thesis is a birth weight in children above 2 SD of the mean birth weight according to the Swedish standard.

NPR

\section{National Patient Register}

Swedish register on statistics of diseases and surgical treatment of patients in Sweden.

$M B R$

Swedish Medical Birth Register

A Swedish register covering data from antenatal care, delivery care and neonatal care.

$S D$

Standard deviation

Statistical term used to quantify the amount of variation in a set of data values. A low value indicates that the data points tend to be very close to the mean value of the set.

SGA Small-for-gestational age

Children born SGA have a lower birth weight than normal for their gestational age. The definition in this thesis is a birth weight in children below 2 SD of the mean birth weight according to the Swedish standard.

TGF $\beta \quad$ Transforming growth factor beta

TGF $\beta$ is a multifunctional cytokine that regulates several functions in different cell types in the body. The cytokine has a role in the pathogenesis of Marfan syndrome.

TPR Total Population Register

A Swedish register containing information related to the population and changes in the population, such as births, deaths, regional migration, immigration and emigration and changes in civil status.

\section{VEGF Vascular endothelial growth factor}

A signal protein produced by cells stimulating the formation of new blood vessels.

VSD Ventricular septal defect

A congenital heart defect consisting of a defect in the wall between the heart's lower chambers. 


\section{Introduction}

Due to advances in medical treatment, increasing numbers of individuals with congenital heart disease (CHD) and Marfan syndrome are reaching childbearing age. Like many other people, these men and women wish to become parents. Pregnancy is a major issue in the management of women with these conditions, due to the substantial physiological changes during pregnancy. Cardiac disease is still one of the most common causes of maternal morbidity and mortality ${ }^{1}$.

\section{Cardiovascular physiology of pregnancy and labor}

Pregnancy causes changes in all maternal organ systems. The reason for these changes involves the increasing metabolic demands of the mother and the fetus. The body also has to adapt to ensure adequate utero-placental circulation for fetal development and growth. The changes start early in pregnancy, and the biggest alterations affect the cardiovascular system ${ }^{2}$.

\section{Hemodynamic changes}

Figure 1 shows the physiological changes during pregnancy.

During the first weeks of pregnancy, plasma volume already increases significantly, and this continues throughout the pregnancy, reaching almost $45 \%$ above preconception values. This is a result of increased sodium retention and increased total water in the body. The high estrogen levels, increased hepatic production of angiotensin, and renin production in the liver, uterus and kidney during pregnancy are responsible for the sodium accumulation. The total body water also increases through several endocrine pathways, including prostaglandins, prolactin, placental lactogen, growth hormones and adrenocorticotropic hormone $(\mathrm{ACTH})^{3}$.

In addition, there is an increase of about $40 \%$ in the production of erythrocytes mediated by progesterone. The increase in plasma volume is higher than the increase in red blood cells, resulting in lower hemoglobin levels. This physiological anemia reduces the viscosity of the blood and can be seen as protection against the relatively high risk of thrombosis during pregnancy. 


\begin{tabular}{|ll|}
\hline Blood volume & $1,51 \uparrow$ \\
Erythrocytes & $2.72-4.43 \times 10^{6} / \mu 1 \uparrow$ \\
Hemoglobin & $110-150 \mathrm{~g} / 1 \downarrow$ \\
Blood pressure & $5-10 / 10-15 \mathrm{mmHg} \downarrow$ \\
Stroke volume & $100 \mathrm{ml} \uparrow$ \\
Heart rate & $15-20 \mathrm{bpm} \uparrow$ \\
Cardiac output & $30-50 \% \uparrow$ \\
\hline
\end{tabular}

Figure 1. Cardiovascular physiological changes of pregnancy

Pregnancy is also associated with systemic vasodilatation related to high estrogen and progesterone levels. Increased levels of endothelial nitrogen monoxide and prostacyclin boost the effect of the female hormones. The vasodilatation mainly affects the utero-placental, renal and cutaneous blood vessels. The change starts in early pregnancy before full placentation and is an important factor in the development of utero-placental circulation. Nearly $20 \%$ of cardiac output is directed to the uterus in the third trimester, compared to approximately $2 \%$ in non-pregnant women.

Systolic and diastolic blood pressures, as well as mean arterial pressure, decrease in pregnancy. The lowest blood pressure occurs in the second trimester, i.e. $5-10 / 10-15 \mathrm{mmHg}$ below baseline, but the change starts as early as the sixth to eighth week of gestation ${ }^{2-4}$.

\section{Cardiac changes}

Most changes in the cardiovascular system start in early pregnancy and reach their highest levels in the second trimester.

The heart grows during pregnancy. Ventricular hypertrophy is associated with volume overload. Studies also show an association with up-regulation of vascular endothelial growth factor (VEGF) and increased angiogenesis in the myocardium. The remodeling of the left ventricular wall affects both thickness and wall mass, with a $28 \%$ and $52 \%$ increase respectively. The right ventricular mass increases by $40 \%$. In the first and second trimester stroke volume increases. At the end of the second trimester stroke volume reaches approximately $100 \mathrm{ml}$, compared to $70 \mathrm{ml}$ in a non-pregnant situation. The 
increase is connected with the remodeling and growing of the heart muscle and the increased plasma volume ${ }^{3}$.

The heart rate also increases during normal pregnancy. This increase is consistent throughout pregnancy, and reaches $15-20$ beats per minute in late pregnancy. The overall change represents a rise of $25-30 \%$ above baseline.

These changes affect cardiac output, which starts to increase in the first trimester. In early pregnancy, this change is due to an increase in stroke volume. Cardiac output increases throughout pregnancy, and is $30-50 \%$ higher in the third trimester than in a non-pregnancy situation. Later, the increase is mostly explained by a higher heart rate r., $^{5,}$

\section{Labor and childbirth}

Cardiac output peaks during labor and immediately after childbirth. In the active phase of labor the increase is approximately $25 \%$ above the levels seen in late pregnancy, and when the woman pushes, an additional increase of about $50 \%$ is observed. This is associated with many different factors. The heart rate increases due to the pain induced by uterine contractions and higher catecholamine secretion. With every contraction, 300 to $500 \mathrm{ml}$ of blood from the uterus are released into the systemic circulation, increasing cardiac preload. The changes after vaginal delivery are also significant. Hemodynamic changes involve blood loss of approximately $500 \mathrm{ml}$. Auto transfusion of blood from the contracted uterus compensates for this blood loss, and the auto transfusion tends to increase cardiac output even further ${ }^{3,7}$.

\section{Long-term outcomes in general after childbirth}

To evaluate the long-term outcomes of pregnancy, several investigations have been conducted on the relationship between reproductive history and causes of death $^{8,9}$.

It is known that pregnancy protects against certain cancers, for example of the breast, ovary and endometrium ${ }^{8,10}$. For cardiovascular disease and coronary heart disease the results are inconsistent. Smaller studies show no difference. However, larger national studies from the United States and the United Kingdom show higher rates of cardiovascular disease and coronary heart disease in multiparous women than in women who have never been pregnant $^{8,9,11}$. 


\section{Congenital heart disease}

\section{Definition}

Congenital heart disease (CHD) is the most common group of malformations, with an incidence of about 8 to 10 in 1000 individuals. About $40 \%$ of cases are detected during the first year of life, and there is great diversity of lesions ${ }^{12}$.

CHD is defined as an abnormality in a cardiovascular structure or function present at birth. The malformations are the consequence of abnormal embryonic development of a structure or the failure of a structure to evolve beyond the early stage of fetal development. Atypical blood flow through the heart, created by an anatomical defect, may also affect the structural or functional development of the heart or the vascular structures of the circulation. This process may occur in utero or during the postnatal period ${ }^{12}$.

This aggravates the chances of detecting heart malformations with ultrasound during pregnancy, or of identifying certain malformations in the postnatal period. For instance, a normal and spontaneous event, such as the closure of the ductus arteriosus a few days after birth, may be central in the development of a symptomatic coarctation of the aorta, and may be difficult to detect prior to closure. The clinical presentation of a malformation can also differ in patients. A ventricular septal defect (VSD) may close spontaneously later in life, or lead to pulmonary hypertension due to increased blood flow to the lungs through the left-right shunt. This illustrates that functional and physiological changes in the heart and circulation can continue throughout life, and it emphasizes the difficulties in categorizing the different malformations ${ }^{12,13}$.

From an anatomical point of view, CHD can be divided into three groups: wall defects, valvular defects and complex defects with more than one lesion present. The lesions can also be divided into groups from a physiological angle: left-toright shunts, cyanotic heart disease, and valvular and vascular conditions. There are also attempts to divide the malformations into groups in terms of clinical severity (Figure 2) $)^{12-14}$. 


\section{Clinical severity}

Simple CHD

Isolated aortic valve disease

Isolated mitral valve disease

Small ASD

Isolated small VSD

Repaired ASD and VSD

Mild pulmonic stenosis

Closed arterial duct

\section{Moderate CHD}

Anomalous pulmonary drainage

AVSD

Coarctation of the aorta

Ebstein anomaly

Ostium primum ASD

Patent arterial duct

Pulmonic valve stenosis

Aortic stenosis

Tetralogy of Fallot

VSD in association with other

defects

\section{Severe $C H D$}

Transposition of the great arteries

Pulmonic stenosis/artresia

Tricuspid atresia

Mitral atresia

Double-outlet ventricle

Single ventricle

Truncus arteriosus

Isomerism, heterotaxy syndromes, ventricular inversion

\section{Physiological approach}

Left-to-right shunts

ASD

VSD

AVSD

Patent arterial duct

Cyanotic heart disease

Tetralogy of Fallot

Transposition of the great arteries

Pulmonic stenosis/artresia

Tricuspid atresia

Valvular and vascular conditions

Aortic stenosis

Aortic insufficiency

Mitral stenosis

Mitral insufficiency

Tricuspid stenosis

Tricuspid insufficiency

Coarctation of the aorta

Truncus arteriosus

Double-outlet ventricle

Figure 2. Categorizations of $C H D$. 


\section{Etiology}

The pathogenesis of CHD is complex. The underlying causes of most cases are only partly known and understood. Epidemiological studies indicate that as many as $80-85 \%$ of cases are caused by multiple factors ${ }^{15}$.

Nevertheless, specific conditions and risk factors are known. There is a strong association with CHD and chromosome abnormalities, such as trisomy 21 and Turner syndrome, but also with micro deletions of chromosomes like DiGeorge syndrome $(22 \mathrm{q} 11)^{16}$. Individuals with certain syndromes such as Marfan, Noonan, and Holt-Oram syndromes are also at higher risk of $\mathrm{CHD}^{15,17}$.

Women with insulin-dependent diabetes mellitus, especially if it is not wellcontrolled, run a greater risk of having a child with $\mathrm{CHD}^{18}$. Certain maternal infections in the first trimester, such as rubella, are also associated with a greater risk of CHD in the offspring ${ }^{19}$.

Certain medications also increase the risk of CHD in offspring, such as antiepileptic drugs and lithium ${ }^{20}$. There is currently an ongoing discussion on the risks associated with the selective serotonin reuptake inhibitor paroxetine, and an increased risk of VSD and atrial septal defects (ASD) in the expected child. However, the results of the studies are not consistent ${ }^{21,22}$. Alcohol and smoking during pregnancy are also known risk factors in terms of CHD in offspring ${ }^{20}$.

The number of single gene mutations known to cause heart defects is growing. Even if more specific genetic mutations are found, they only represent a small percentage of cases of $\mathrm{CHD}^{15}$.

The risk of children of individuals with CHD also having a heart defect has been described in a number of studies. The recurrence rates vary from $2-20 \%$ depending on the lesion ${ }^{15,23-25}$. The risk is higher if the mother is affected rather than the father ${ }^{24-26}$.

\section{Advances in therapy}

Since the 1950s there have been considerable improvements in medical treatment for children with cardiac malformations. Today more than $90 \%$ of individuals with CHD survive into adulthood, and the number of adults with CHD is greater than the number of children with the condition ${ }^{27,28}$. The advances cover all fields, from chorionic villus sampling for genetic conditions and prenatal ultrasound diagnostics to medical treatments of CHD. 
Chorionic villus sampling is a test to determine genetic disorders in the fetus, and may be used when individuals have known genetic disorders or mutations. The first attempt to perform a biopsy of chorionic tissue was made in 1968, but the procedure was associated with high rates of bleeding and infection. In 1983, an Italian group introduced the procedure performed today, with low risk of complications $^{29}$. The number of detectable genetic disorders is still increasing, and today more than 200 disorders of this type can be detected. There are no specific tests for mutations which cause CHD, but many conditions associated with CHD, such as Marfan and DiGeorge syndromes, can be diagnosed in the fetus ${ }^{15}$.

Advances in ultrasound technology have made the detection of fetal cardiac malformations more precise, and it is possible to diagnose malformations earlier in pregnancy ${ }^{13}$. The detection of severe cardiac malformations in utero enables obstetricians, neonatologists, pediatric cardiologists and pediatric cardiac surgeons to optimize postnatal care of affected children.

The introduction of cardiopulmonary bypass machines in the 1950s was the most important step in the development of pediatric heart surgery. The device takes over the function of heart and lungs during surgery, which increases the available operation time in surgical procedures. During the first 20 years of its use, mortality decreased rapidly in open-heart surgery ${ }^{30}$.

The possibility of keeping the arterial duct open after birth with prostaglandins gives neonatologists time to optimize the condition of the children before surgery $^{31}$.

The results of pediatric heart surgery have also improved with the development of surgical techniques. In many cases it is possible nowadays to restore normal anatomical conditions in the heart. These advances mean that many individuals with CHD have no need to use medication when they are not pregnant ${ }^{28}$.

\section{Long-term outcomes after childbirth}

Because of prior surgical procedures, individuals with CHD are at increased risks of cardiac arrhythmia and developing ventricular dysfunction ${ }^{32-34}$. The risk of adverse cardiovascular outcomes after childbirth in women with CHD has not been well studied. Some small studies and a few larger ones have investigated the various congenital malformations separately $y^{35-37}$. Balint and Kampman have reported an increased risk of adverse cardiovascular events such as heart failure, cardiac arrhythmia, thromboembolic events and myocardial 
infarction postpartum where women had cardiovascular events during pregnancy ${ }^{35,36}$. More studies are needed to evaluate further the risks after childbirth for women with CHD.

\section{Marfan syndrome}

\section{Definition}

Marfan syndrome is a disorder of the connective tissue. The estimated incidence is $2-3$ in $10000^{38}$. It is a complex syndrome associated with clinical manifestations in multiple organ systems, typically cardiovascular, skeletal and ocular $^{39}$. Diagnosis today is made using the revised Ghent criteria, which were defined by an international expert panel in 1986, 1996 and $2009^{40}$. The revised Ghent criteria from 2009 are presented in Figure 3. Aortic root aneurysm, or dissection, and ectopia lentis are cardinal clinical manifestations ${ }^{40}$.

\section{Etiology}

In about $75 \%$ of cases the condition is inherited, and $25 \%$ are new genetic mutations. Inheritance is autosomal dominant ${ }^{41}$. Marfan syndrome is caused by a mutation of the FBN1 gene, located on chromosome 15(15q21), which encodes for fibrillin-1, a glycoprotein of the extracellular matrix ${ }^{42}$. A mutation in the gene can be found in about $97 \%$ of individuals with classic Marfan syndrome $^{40}$. However, the presence of a mutation in the gene alone does not automatically lead to a diagnosis of Marfan syndrome, since the gene can lead to a variety of syndromes depending on how it is mutated ${ }^{43}$.

More than 1000 specific mutations for Marfan syndrome are known. Molecular genetic testing is available for mutations in FBN1, and can be used when the clinical situation is uncertain ${ }^{39}$.

Many aspects of Marfan syndrome may be caused by modified regulation of transforming growth factor $\beta$ (TGF $\beta)^{38}$. TGF $\beta$ is a family of cytokines that regulate a number of functions in many cell types such as macrophages, $\mathrm{T}$ - and B-lymphocytes. The multifunctional peptides control proliferation, differentiation, adhesion and migration in the cells. The protein regulates many other growth factors in cells with the TGF $\beta$ receptor ${ }^{39}$. 
In absence of family history:

- Aortic root dilatation and ectopia lentis

- Aortic root dilatation and FBNI

- Aortic root dilatation and $\geq 7 \mathrm{p}$ of systemic features

- Aortic root dilatation and ectopia lentis and FBN1

\section{Systemic features}

- Wrist and thumb sign $-3 p$ (wrist or thumb sign $-1 p$ )

- Pectus carinatum deformity $-2 p$ (pectus excavatum or chest asymmetry $-1 p$ )

- Hindfoot deformity $-2 p$ (plain pes planus $-1 p$ )

- Pneumothorax $-2 \mathrm{p}$

- Dural ectasia - $2 \mathrm{p}$

- Protrusio acetabuli $-2 \mathrm{p}$

- Reduced US/LS and increased arm/height and no severe scoliosis - 1p

- Scoliosis or thoracolumbar kyphosis - 1p

- Reduced elbow extension - $1 \mathrm{p}$

- Facial features - 1p (enophthalmos, dolichocephaly, downslanting palpebral fissures, malar hypoplasia, retrognathia)

- $\quad$ Skin striae - $1 \mathrm{p}$

- $\quad$ Myopia $>3$ diopters $-1 \mathrm{p}$

- Mitral valve prolapse - $1 \mathrm{p}$

Maximum total: 20 points; score $\geq 7 \mathrm{p}$ indicates systemic involvement
- Family history and ectopia lentis

- Family history and $\geq 7 \mathrm{p}$ of systemic features

Family history and aortic root dilatation 
individuals with less severe symptoms receive a diagnosis of Marfan syndrome as more genetic tests are performed.

Even with excellent surgical results, the main goal of medical treatment is to avoid the need for surgery. The results of studies using $\beta$-adrenergic blockage have not been conclusive, but $\beta$-blockage is still widely used in centers, which manage patients with Marfan syndrome ${ }^{43,47}$. Approaches have also been tried with ACE-I blockers and angiotensin receptor blockers, but unfortunately the results are no better than with $\beta$-blockage ${ }^{47,48}$.

The main causes of death are still aortic aneurysm dissection and rupture ${ }^{49}$.

\section{Long-term outcomes after childbirth}

There are few studies on the cardiovascular risks after childbirth in women with Marfan syndrome. The studies investigate changes in the diameter of the aortic root and the risk of aortic dissection during and after pregnancy. However, the results are not consistent.

The first study on long-term outcomes after pregnancy found no worsening of aortic root diameters after childbirth and no increased risk of dissection ${ }^{50}$. The second study from 2005 showed increased risk of growth in the aortic root diameter if the diameter was greater than $40 \mathrm{~mm}$ in early pregnancy ${ }^{51}$. The third study found increased growth of aortic root diameter during pregnancy and the diameters did not return to baseline after pregnancy. The prevalence of elective aortic replacement and aortic dissection during long-term follow-up was higher in women with Marfan syndrome who had been pregnant than in women with Marfan syndrome without pregnancy ${ }^{52}$.

The differences in results of the studies are probably due to different methodological approaches, small study populations in different settings, and the fact that the studies were performed in 1995, 2005 and $2012^{50-52}$. 


\section{Adverse outcomes of pregnancy and childbirth}

Preterm birth and being born small-for-gestational age (SGA) are risk factors for the infant but also later in adulthood. Preterm birth is seen in 5-8 \% of all pregnancies in Europe $^{53}$.

The outcomes for preterm infants have improved greatly over the last 30 years. Generally, the outcomes improve with increasing gestational age and higher birth weight. Infants born after 32 weeks of gestation have almost similar outcomes as term infants. However, preterm birth is still associated with increased risks for the child since many body organs are not fully developed at birth $^{54}$. Especially infants born before 28 weeks of gestation are at risk of serious problems, such as brochopulmonary dysplasia, intraventricular hemorrhage, infections, and patent arterial duct with the risk of heart failure ${ }^{55}$.

Long-term complications of preterm birth include impaired cognitive skills, vision and hearing problems, and behavioral and psychological problems, such as attention-deficit/hyperactive disorder ${ }^{55,56}$. Children who experienced preterm birth are also more likely to have chronic health issues such as asthma and infections than full-term children ${ }^{54,55}$.

SGA babies comprise approximately $50 \%$ of all stillbirths ${ }^{57,58}$. Children born SGA are at increased risk of cardiovascular disease and diabetes in adulthood $^{59,60}$.

\section{Congenital heart disease}

Pregnancy in women with CHD is associated with increased risks for the expected child.

There are studies showing increased risk of preterm birth in women with $\mathrm{CHD}^{61,62}$. The risk of preterm labor and preterm birth is associated with both maternal and fetal factors in women with $\mathrm{CHD}^{63,64}$. Other increased risks for the newborn of women with CHD are birth weights below 2500 grams and being born $\mathrm{SGA}^{61-63}$.

Moreover, cesarean section rates in women with CHD are higher than in the general population ${ }^{61,64,65}$. These findings have been reproduced in several studies, but frequencies vary as a consequence of different traditions and management of labor in different countries ${ }^{61}$. 


\section{Marfan syndrome}

Pregnancy outcomes in women with Marfan syndrome have not been widely studied, and the results are inconsistent.

Some studies indicate an increased risk of preterm birth $^{66,67}$. Others find no differences compared to women without the condition ${ }^{52,68}$. SGA has also been investigated, and an increased risk was seen in some studies, where others have been unable to verify the risk ${ }^{50,66-69}$.

Cesarean section is recommended if the aortic diameter is dilated. However, there has been a discussion about the limits. Today, if the aortic diameter exceeds $4-4.5 \mathrm{~cm}$, a cesarean section is recommended ${ }^{49,70}$. The aorta is dilated during normal pregnancy, and there is also an increased risk of aortic dissection during pregnancy in healthy women, although the risk of dissection is $1 \mathrm{lw}^{71}$. In women without predisposed conditions for aortic dissection, approximately one woman in 200000 women suffer from aortic dissection during pregnancy ${ }^{72}$. The change in aortic diameter is mediated hormonally. It involves a decrease in the amount of mucopolysaccharides and a loss of elastic fibers in the aortic wall during pregnancy ${ }^{73,74}$.

Previous studies have evaluated the risk of aortic dissection during pregnancy in women with Marfan syndrome, and the results indicate a risk of approximately $4-7 \%$ during pregnancy ${ }^{50,75-77}$. The described risk varies, which may indicate a change in treatment over the years since the newer studies indicate lower risks of dissection, if the diagnosis of Marfan syndrome is set prior to pregnancy ${ }^{51,78}$. 


\section{Specific background to the present studies}

Until recently, women with CHD were often advised against pregnancy, due to concern about the increased medical risks it could pose. These women constitute a relatively new challenge for obstetricians, anesthesiologists and cardiologists in terms of surveillance, treatment and care during pregnancy and childbirth. Early studies analyzed pregnancy outcomes in a combination of women with CHD and acquired heart disease ${ }^{79-81}$. This made it impossible to evaluate the specific risks for women with CHD. There were no national population-based studies.

The idea for Paper II originated from clinical experience of fathers-to-be with CHD, and their concerns about the risk of adverse outcomes for the expected child. The birth characteristics of this group of individuals, their reproductive patterns and the consequences for their children had not previously been investigated to our knowledge.

Since Swedish registers contain data on both parents of children, it is possible to link a child to the father, and to investigate men with CHD, as well as how this manifests itself in their children.

Marfan syndrome is a rare condition with great impact on the cardiovascular situation in individuals with the condition. In earlier studies, pregnancy outcomes in women with Marfan syndrome were analyzed together with outcomes in women with $\mathrm{CHD}^{80,81}$. Pregnancy in women with Marfan syndrome is difficult to study, due to the small number of women with the condition. Most previous studies describe pregnancy outcomes in primi- and multiparous women without dividing the women into groups ${ }^{50,66,67,78}$. This makes the results difficult to interpret, as it is known that there is a higher risk of adverse outcomes in subsequent pregnancies after adverse outcomes during a first pregnancy ${ }^{82,83}$.

The long-term outcomes after childbirth in women with Marfan syndrome have focused on aortic complications and nothing else $\mathrm{e}^{50-52}$. 


\section{Aims}

- To describe the socio-demographic and birth characteristics of individuals with CHD and women with Marfan syndrome.

- To describe the reproductive pattern of individuals with CHD and women with Marfan syndrome.

- To investigate the obstetric outcomes of the first birth in women with CHD and women with Marfan syndrome.

- To investigate the neonatal outcomes of firstborn children of individuals with CHD and of women with Marfan syndrome.

- To describe the cardiovascular outcomes after childbirth in women with Marfan syndrome. 


\section{Material and methods}

Swedish population-based registries provided data for these studies. Since every Swedish citizen has a unique personal identity number, the data in different registries can be cross-referenced.

The medical diagnoses registered are based on the Swedish version of the International Statistical Classification of Diseases and Related Health Problems (ICD). Different versions of the classification system have been in use as follows: ICD-8-SE was used until 1986, ICD-9-SE was used between 1987 and 1996, and ICD-10-SE from 1997.

\section{Study design and study population}

\section{Classification of CHD (Papers I and II)}

Individuals with CHD were divided into groups, "simple CHD" and "complex CHD" (Figure 4). The main diagnoses from the National Patient Register (NPR) and from the Medical Birth Register (MBR) were used in the classification.
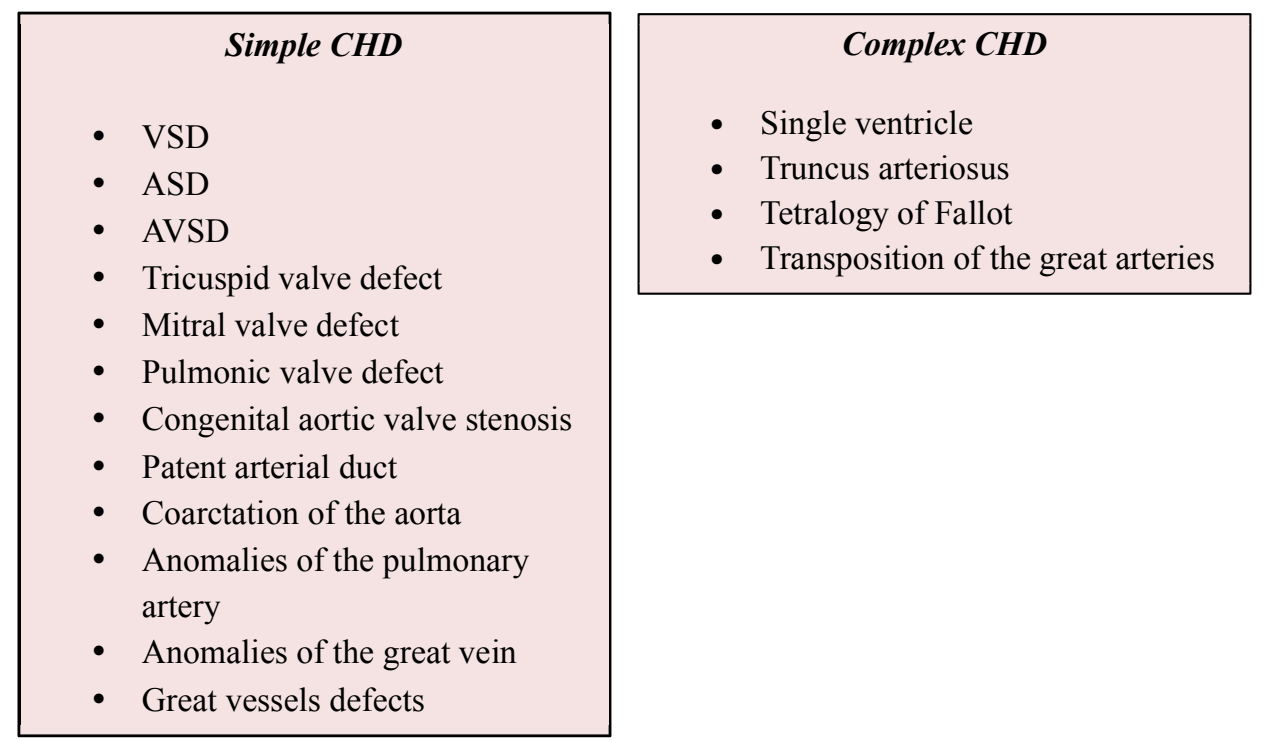

Figure 4. Categorization of CHD in Papers I and II. 


\section{Paper I}

For this paper, a national population-based register study was conducted to investigate reproductive patterns of women with CHD and obstetric and neonatal outcomes of their first childbirth.

The cohort consisted of all Swedish women born between 1973 and 1983. To be included in the study population they had to be living in Sweden at 13 years of age. The women were followed until the end of 2006. The data set was "cleaned", i.e. individuals were removed from the study population if they died or emigrated from Sweden before the age of 13, if there were missing values on birth weight and/or gestational length and if the birth weight was unlikely low or high with respect to gestational length.

Figure 5 shows the exclusion criteria for extreme outliers, and Figure 6 shows the flowchart indicating how the study population in Paper I was formed.

The final study population consisted of 494692 individuals, of whom 2216 were women with CHD. Of the women in the study population, 188867 had become mothers during the study period, and of these, 47 women with complex CHD and 644 simple CHD were available for analysis.

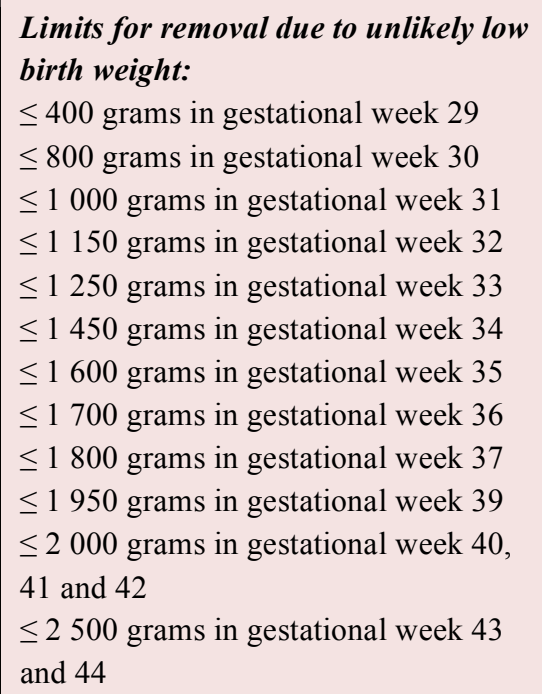

Figure 5. Exclusion criteria for extreme outliers.

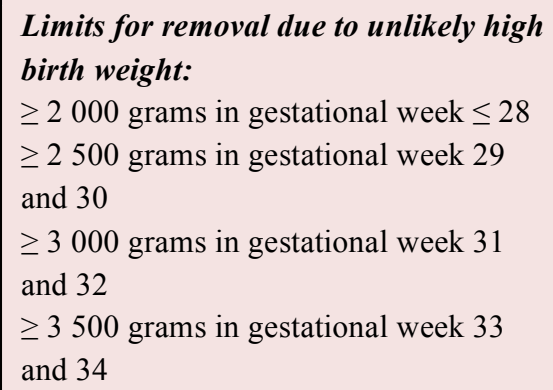




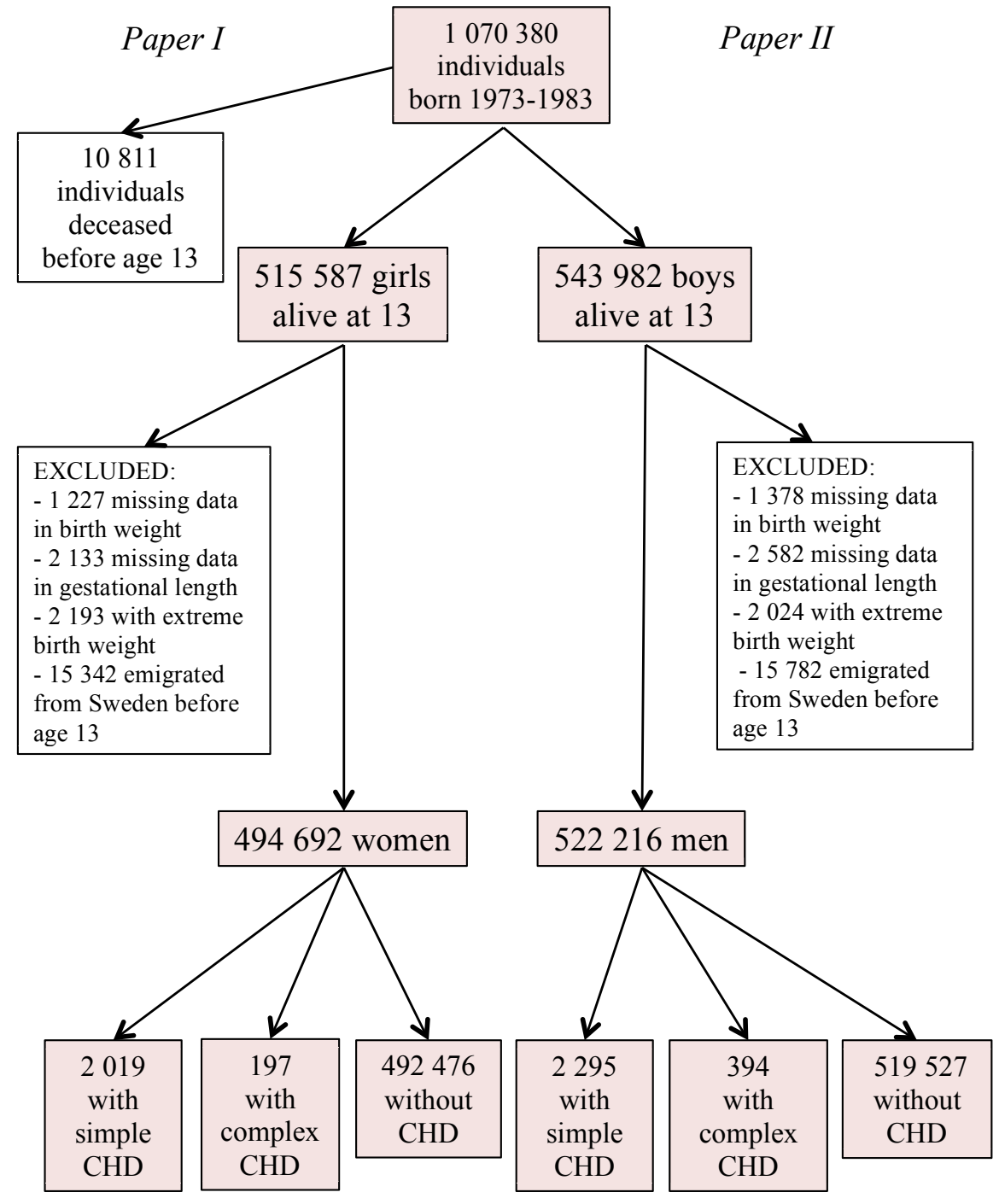

Figure 6. Flowchart of study population in Papers I and II. 


\section{Paper II}

This population-based register study has a similar study design to the one in Paper I. The aim was to investigate reproductive patterns of men with CHD and obstetric and neonatal outcomes of their firstborn children.

The study population was followed until the end of 2006, and comprised men born between 1973 and 1983 in Sweden who were alive and resident in Sweden at 13 years of age. Figure 6 shows the flowchart for the exclusion of study participants in Paper II.

The final study population involved 522216 men. Of these, 2689 men had been diagnosed with CHD. 110419 of the men had become fathers. Fifty-four men with complex CHD and 321 men with simple CHD had become fathers during the study period and were available for analysis.

\section{Paper III}

To evaluate the obstetric and neonatal outcomes of the firstborn child of women with Marfan syndrome, a nationwide population-based cohort analysis and a matched case-control study were performed.

Marfan syndrome was defined as 759,80 in ICD-8, $759 \mathrm{~W}$ in ICD-9 and as Q87.4 in ICD-10.

The original cohort consisted of all Swedish women born between 1973 and 1993 who were resident in Sweden at the age of 13. The procedure followed to form the study population is presented in Figure 7.

The final study population consisted of 1017538 individuals. Two hundred and seventy-three of these women were diagnosed with Marfan syndrome. 364553 women had given birth, and of these, 61 women had Marfan syndrome.

Women with Marfan syndrome served as cases for the case-control study. For each case, two matched controls were selected who did not have Marfan syndrome. The matching was by age and year of giving birth.

The study population was followed until 2013. 


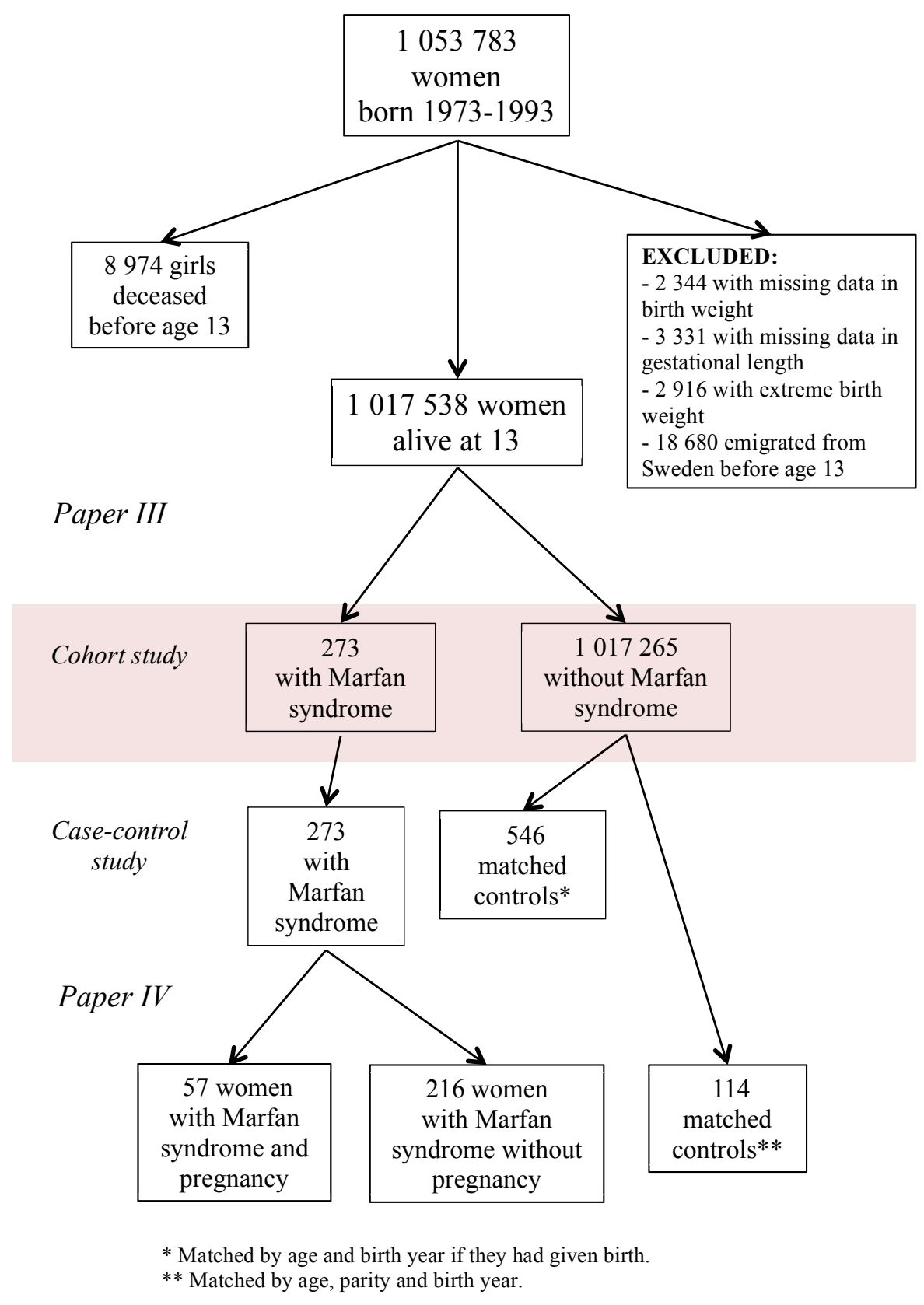

Figure 7. Flowchart of study population in Papers III and IV. 


\section{Paper IV}

For this paper, the long-term cardiovascular outcomes of childbirth in women with Marfan syndrome were explored in a case-control study. The hypothesis was that there is an increased risk of cardiovascular complications after childbirth in women with Marfan syndrome.

The study population from Paper III was used to find appropriate cases and controls for the analysis. Figure 7 shows the flowchart indicating how the study population was formed.

Three groups of women were selected for comparisons.

The cases were women born between 1973 and 1993 who had been diagnosed with Marfan syndrome and who had given birth between 1995 and $2010(\mathrm{n}=57)$. Two control groups were formed. One group involved women who had not been diagnosed with Marfan syndrome, matched by age, parity and the year they had given birth. In this group, two controls were selected for each woman with Marfan syndrome $(\mathrm{n}=114)$. The second group consisted of women with Marfan syndrome who had not given birth $(n=216)$. The study population was followed until 2013.

The cardiovascular diagnoses investigated are presented in Figure 8. We also investigated the surgical codes for aortic reconstruction (ICD-10 FC), insertion of pacemakers and implantable cardioverter defibrillators (ICD-10 FP), valvular reconstruction and replacement of the valves (ICD-10 FG, FK, FM), and for surgery to correct cardiac arrhythmia (ICD-10 FP). Cardiovascular diagnoses were investigated prior to, during and after pregnancy.

\section{Socio-demographic characteristics, obstetric and neonatal outcomes}

Papers I-III included data on the educational level and country of origin of the parents of the studied individuals, as well as the marital status, age at pregnancy and parity of the mother of each individual.

Educational levels were divided into three groups: 9-10 years, 11-13 years and $\geq 14$ years of education. Missing data were referred to as a fourth group.

Marital status was grouped as married, divorced/widowed and not married.

Four age groups were defined for the age of the mother of each individual in the study: 13-19, 20-26, 27-33 and $\geq 34$ years of age. 
I 10: Essential hypertension

I 11: Hypertensive heart disease

I 20-22, 24: Ischemic heart disease

I 26-28: Diseases of pulmonary circulation

I 30-33, 38-39: Pericarditis and endocarditis

Hypertension

I 34: Mitral valve disorders

I 35: Aortic valve disorders

I 36: Tricuspid valve disorders

I 37: Pulmonary valve disorders

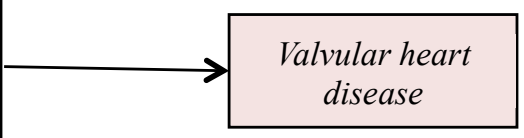

I 40-41: Myocarditis

I 42: Cardiomyopathy

I 44-45: Heart blocks

I47-49: Cardiac arrhythmia

I 46: Cardiac arrest

I 50: Heart failure

I 70: Atherosclerosis

I 71: Aortic aneurysm and dissection

I 72: Other aneurysm and dissection

I 74: Arterial embolism and thrombosis

Figure 8. Cardiovascular diagnoses studied in women with Marfan syndrome.

Parity and country of origin were divided into two groups respectively: previous or no previous children, and both Nordic origin or one/both non-Nordic origin.

Characteristics related to the studied individuals' own birth were investigated, such as birth weight, gestational length, preterm birth, SGA, large-forgestational age (LGA), twin birth and mode of delivery. The same characteristics were investigated for the firstborn children of these individuals.

In Papers I and II, the registered malformations of the children were also investigated. The diagnoses were retrieved from the MBR.

In Papers I-III, socio-demographic characteristics of the studied individuals were investigated. These included age, educational level, and marital status at the time of becoming a parent. 
They were all defined as noted above except for age, since our population consisted of young women. The groups were defined as 13-19, 20-24 and $\geq 25$ years of age.

The women's smoking habits and body mass index (BMI) also were described. Smoking habits were grouped as smoking and not smoking. Five BMI groups were formed, and an additional one for missing values: <20, 20-24.9, 25-29.9, 30-34.9 and $\geq 35$.

Diagnoses of hypertension and diabetes mellitus during pregnancy were also investigated.

\section{Registers}

\section{The Swedish Medical Birth Register (MBR) (Papers I-IV)}

The Swedish National Board of Health and Welfare holds the register that has collected data from antenatal care, delivery care and neonatal care since 1973. In the register, the coverage of births in Sweden is high, at approximately $99 \%$. Every health-care provider is required to register information from pregnancies and births ${ }^{84}$. The quality of the register has been evaluated in 1976, in 1988 and in $2001^{85,86}$.

Specific data are recorded, such as previous pregnancies, smoking habits, maternal medical drug use during pregnancy, gestational length, analgesia during labor, delivery mode, specific diagnoses of the mother, and surgical procedures. Neonatal outcomes are also recorded, such as the sex of the child, birth weight, birth length, head circumference, single or multiple pregnancies, Apgar score and diagnoses relating to the infant.

\section{The National Patient Register (NPR) (Papers I-IV)}

The purpose of the register is to follow the progress of health in the Swedish population, to improve the chances of preventing and treating diseases and to develop the Swedish health-care system. The NPR has been in use since the 1960s, and is held by the Swedish National Board of Health and Welfare. Initially, the register did not cover the entire Swedish population, but since 1987 all public, inpatient care has been recorded in the NPR ${ }^{87}$. The data submitted are controlled and compared to medical records to ensure validity of the register ${ }^{88}$. 
The register continuously receives information on patient and hospital-related data. This includes medical diagnoses, external cause of injury and surgical procedures. The register has expanded, and since 2001 has also contained information on outpatient visits, such as day surgery and psychiatric care from both public and private care providers. About one percent of the cases in the register have missing main diagnoses, but the frequencies vary between the counties in Sweden and the different medical specialties.

\section{The Total Population Register (TPR) and the Multi-Generation Register (Papers I-III)}

The TPR is maintained by Statistics Sweden, and was started in 1968. The register contains information relating to the population and changes in the population. Information is registered on births, deaths, regional migration, immigration and emigration and changes in civil status ${ }^{89}$.

The Multi-Generation Register is part of the TPR, and was created to focus on child-parent relationships, both biological and adoptive. The register makes it possible to identify the parents of the index persons, and contains all individuals born in Sweden since 1932.

\section{The Causes of Death Register (Papers I-IV)}

The purpose of this register is to describe the causes of deaths of individuals in Sweden and to follow tendencies in causes of deaths. It is categorized by age and sex. The register was established in 1961, and is held by the Swedish National Board of Health and Welfare ${ }^{90}$.

\section{The Swedish Register of Education and the Population and Housing Census 1970 (Papers I-III)}

Since 1985, Statistics Sweden has used the Register of Education to collect information on the educational level of the population. It is updated once a year. Earlier registers on educational levels in the population were produced in 1930 and 1970. The main variables concerning education are highest educational level and year of completion ${ }^{91,92}$. 


\section{Statistics}

In the descriptive statistics for continuous variables, the mean and standard deviation (SD) were presented; for discrete variables numbers and percentages were presented.

The t-test was used for comparing mean values, and the chi-squared test was used for comparing categorical values (Papers I and III). A two-sided $p$ value of $<0.05$ was considered statistically significant. If there were more than two groups to compare an analysis of variance was preformed initially to compare the groups.

In Paper II, comparisons between the groups complex CHD, simple CHD and non-CHD were made for continuous variables such as birth weight and gestational length, through an analysis of variance corrected with the TukeyKramer procedure.

In Papers I and II, the hazard ratio for the likelihood of becoming a parent, and the corresponding 95\% confidence intervals (CI), were calculated using the Cox proportional hazards model. Age was used to define the time dimension in this analysis, and individuals exited from the model when they had a child, emigrated or died, depending on which came first. Adjustments were made for socio-demographic characteristics as follows: educational levels of the parents, mother's age, mother's marital status, mother's parity, parents' country of origin.

In Papers I and II, multiple logistic regression was used to compare obstetrical and neonatal outcomes of the first childbirth. Data were adjusted for sociodemographic background information and for the specific cardiac malformation.

Due to the small sample size in Paper IV, we mainly presented the results as numbers (n) and percentages (\%). To investigate potential differences in the presence of cardiovascular disease we used Fisher's exact test and calculated pvalues.

The statistical software IBM SPSS Version 22 (IBM SPSS Inc., Armonk, NY) was used for all analyses. 


\section{Ethical considerations}

The Regional Ethical Review Board in Linköping, Sweden approved the studies included in this thesis, nos. 2010/402-31 and 2014/112-31.

Due to the high quality of Swedish national registers, data from them are used in many studies today. The data are provided from Statistics Sweden and the Swedish National Board of Health and Welfare, and an approval from a Regional Ethical Review Board is mandatory for accessing data from the registers. Even ethical approval does not ensure that a research group can access an extract from the registers, since the agencies also review the planned studies and make a decision about whether the data will be released to the research group.

These studies are based on registered data and do not involve any interaction with the individuals studied. Therefore the Regional Ethical Review Board does not require a personal consent from the individuals in order to approve the studies, which would otherwise be customary. In Sweden, individuals have the opportunity to choose not to participate in quality registers.

It is nevertheless of great importance not to be able to identify separate individuals in studies, so that the personal integrity of the individuals is not infringed. Therefore, data sets should be used without personal identifiers such as personal identity numbers, and data should be presented in such a way that it is impossible to identify individuals.

The data in population-based registers can been used to examine a number of important areas in which other study designs may be unethical or difficult to use. Pregnancy is a situation where it is hard to design randomized studies. Outcomes in rare conditions are also difficult to examine in randomized trials. The large population involved in registers offers an opportunity to investigate rare diseases. 


\section{Results and comments}

\section{Birth characteristics of individuals with CHD}

The socio-demographic characteristics of the parents of women and men with CHD, as well as the specific characteristics of the women and men at birth, were of high correspondence. The mothers of the individuals with CHD were older and more likely to be unmarried compared to mothers of children without CHD. Individuals with CHD were more likely to be born preterm and SGA, and men with CHD were also more likely to be born LGA compared to individuals without CHD. Deliveries were more often cesarean sections compared to deliveries of children not diagnosed with CHD.

\section{Specific results in Paper I: Women with CHD}

In the study population of 494692 women, $2216(0.45 \%)$ had been diagnosed with CHD. Complex CHD was found in 197 (8.9\%). There were no deaths during pregnancy or in the first year after childbirth in women with CHD.

Women with CHD had significantly lower birth rates compared to individuals without CHD, but they were significantly more likely to have given birth during the study period; Hazard ratio $=1.140(95 \%$ CI 1.058-1.228), $\mathrm{p}=0.001$, after adjustments were made for parental socio-demographic characteristics. They were also younger at the time of their first pregnancy compared to women without CHD.

Children of women with CHD were more likely to be born preterm, SGA and by cesarean section (Table 1). Birth weights and gestational lengths were significantly lower than in children of women not diagnosed with CHD. There was also a higher rate of malformations in the offspring of women with CHD. There were no significant differences in the neonatal outcomes of the children of women with simple compared to complex CHD. When the variables; preterm birth, SGA, cesarean section, congenital malformations were analyzed simultaneously with multiple logistic regression, all associations remained significant. 


\begin{tabular}{|c|c|c|c|c|c|c|c|}
\hline \multirow[b]{3}{*}{ Chi-squared test } & \multicolumn{3}{|c|}{ CHD } & & \multicolumn{2}{|c|}{ No CHD } & \multirow[b]{3}{*}{ p-value } \\
\hline & \multicolumn{2}{|c|}{ Complex } & \multicolumn{2}{|c|}{ Simple } & \multirow[b]{2}{*}{$n$} & \multirow[b]{2}{*}{$\%$} & \\
\hline & $n$ & $\%$ & $n$ & $\%$ & & & \\
\hline Preterm birth & & & & & & & $0.001^{1}$ \\
\hline Yes & 7 & 14.9 & 56 & 8.7 & 11636 & 6.2 & $0.008^{2}$ \\
\hline No & 40 & 85.1 & 588 & 91.3 & 176540 & 93.8 & $0.154^{3}$ \\
\hline Born SGA & & & & & & & $0.076^{1}$ \\
\hline Yes & 2 & 4.3 & 21 & 3.3 & 3971 & 2.1 & $0.043^{2}$ \\
\hline No & 45 & 95.7 & 623 & 96.7 & 184205 & 97.9 & $0.714^{3}$ \\
\hline Born LGA & & & & & & & $0.853^{1}$ \\
\hline Yes & 1 & 2.1 & 22 & 3.4 & 5911 & 3.1 & $0.690^{2}$ \\
\hline No & 46 & 97.9 & 622 & 96.6 & 182265 & 96.9 & $0.635^{3}$ \\
\hline Twin birth & & & & & & & $0.265^{1}$ \\
\hline Yes & 0 & 0.0 & 5 & 0.8 & 2702 & 1.4 & $0.160^{2}$ \\
\hline No & 47 & 100.0 & 639 & 99.2 & 185474 & 98.6 & $0.544^{3}$ \\
\hline Cesarean section & & & & & & & $<0.001^{1}$ \\
\hline Yes & 11 & 23.4 & 124 & 19.3 & 27049 & 14.4 & $<0.001^{2}$ \\
\hline No & 36 & 76.6 & 520 & 80.7 & 161127 & 85.6 & $0.489^{3}$ \\
\hline Congenital malfor & ns & & & & & & $<0.001^{1}$ \\
\hline Yes & 5 & 10.6 & 43 & 6.7 & 6867 & 3.6 & $<0.001^{2}$ \\
\hline No & 42 & 89.4 & 601 & 93.3 & 181309 & 96.4 & $0.302^{3}$ \\
\hline
\end{tabular}
Overall comparison.
Comparison between simple and no CHD.
Comparison between complex and simple.

\section{Specific results in Paper II: Men with CHD}

The study population consisted of 522216 men born in Sweden between 1973 and 1983. A diagnosis of CHD was present in 2689 (0.5\%), and 394 of these had a complex malformation according to the classification used.

Men with CHD were less likely to become parents than men with no diagnosis of CHD ( $p<0.001)$. This result was confirmed by a Cox regression analysis with adjustments made for parental socio-demographic characteristics; Hazards ratio $=0.767$ (95\% CI 0.697-0.845). The incidence of fathering did not differ if the men with CHD had a child with a woman with CHD or a woman without CHD; Hazards ratio $=0.210(95 \%$ CI $0.031-1.426)$

No differences were found in the risks of adverse outcomes for the children of men with CHD compared to the children of men not diagnosed with CHD. 


\section{Birth characteristics of women with Marfan syndrome}

The socio-demographic characteristics of the parents of women with Marfan syndrome did not differ from the parents of women without Marfan syndrome. Women with Marfan syndrome were more often born preterm, with low birth weight $(<2500$ grams) or SGA, than women without Marfan syndrome. They were also more often born by cesarean section. These results are consistent in the analyses of the cohort and of the case-control studies (Table 2).

\begin{tabular}{|c|c|c|c|c|c|c|c|c|}
\hline \multirow[b]{4}{*}{ t-test } & \multicolumn{8}{|c|}{ Marfan syndrome } \\
\hline & \multicolumn{2}{|c|}{ Yes } & \multicolumn{6}{|c|}{ No } \\
\hline & \multirow[b]{2}{*}{ mean } & \multirow[b]{2}{*}{$S D$} & \multicolumn{3}{|c|}{ Cohort } & \multicolumn{3}{|c|}{ Case-control } \\
\hline & & & mean & $S D$ & p-value & mean & $S D$ & p-value \\
\hline Birth weight (g) & 3267 & 610 & 3437 & 532 & $<0.001$ & 3440 & 488 & $<0.001$ \\
\hline $\begin{array}{l}\text { Gestational } \\
\text { length (weeks) }\end{array}$ & 39.0 & 2.2 & 39.5 & 1.8 & $<0.001$ & 39.6 & 1.7 & $<0.001$ \\
\hline Chi-squared test & $n$ & $\%$ & $n$ & $\%$ & & $n$ & $\%$ & \\
\hline Preterm birth & & & & & $<0.001$ & & & $<0.001$ \\
\hline Yes & 29 & 10.6 & 50203 & 4.9 & & 22 & 4.1 & \\
\hline No & 244 & 89.4 & 967062 & 95.1 & & 521 & 95.9 & \\
\hline Low birth weight & & & & & $<0.001$ & & & $<0.001$ \\
\hline Yes & 27 & 9.9 & 41211 & 4.1 & & 20 & 3.7 & \\
\hline No & 246 & 90.1 & 976054 & 95.9 & & 523 & 96.3 & \\
\hline Born SGA & & & & & $<0.001$ & & & 0.02 \\
\hline Yes & 21 & 7.7 & 36106 & 3.5 & & 21 & 3.9 & \\
\hline No & 252 & 92.3 & 981159 & 96.5 & & 522 & 96.1 & \\
\hline Twin birth & & & & & 0.833 & & & 0.005 \\
\hline Yes & 4 & 1.5 & 19709 & 1.9 & & 0 & 0.0 & \\
\hline No & 269 & 98.5 & 997388 & 98.1 & & 543 & 100.0 & \\
\hline Cesarean section & & & & & 0.007 & & & 0.001 \\
\hline Yes & 41 & 15.0 & 103052 & 10.1 & & 40 & 7.4 & \\
\hline No & 232 & 85.0 & 914213 & 89.9 & & 503 & 92.6 & \\
\hline
\end{tabular}




\section{Specific results in Paper III: Women with Marfan syndrome}

The prevalence of Marfan syndrome in this study was 2.7 in 10000 ; of all 1017 538 women in the study population, 273 had a diagnosis of Marfan syndrome. Twenty-five girls with Marfan syndrome deceased before the age of 13 and were excluded from the study population from the start: 20 women with Marfan syndrome died after the age of 13. No deaths in women with Marfan syndrome occurred during or after pregnancy.

Women with Marfan syndrome were less likely to have given birth $(\mathrm{p}<0.001)$. None of the women with Marfan syndrome had hypertension or diabetes at the time of pregnancy.

In the neonatal outcomes of their firstborn children, no statistically significant differences were found compared to children of women without Marfan syndrome in the case-control analysis (Table 3). In the cohort analysis, statistical significance was found for being born with a birth weight below 2500 grams $(\mathrm{p}=0.037)$. Nineteen of the women with Marfan syndrome were delivered by cesarean section (31.1\%) compared with $16.1 \%$ of the women in the cohort population $(\mathrm{p}<0.001)$ and $19.5 \%$ of the matched controls $(\mathrm{p}=0.08)$.

\begin{tabular}{|c|c|c|c|c|c|c|c|c|}
\hline \multirow[b]{4}{*}{ Chi-squared test } & \multicolumn{8}{|c|}{ Marfan syndrome } \\
\hline & \multicolumn{2}{|c|}{ Yes } & \multicolumn{6}{|c|}{ No } \\
\hline & \multirow[b]{2}{*}{$\mathbf{n}$} & \multirow[b]{2}{*}{$\%$} & \multicolumn{3}{|c|}{ Cohort } & \multicolumn{3}{|c|}{ Case-control } \\
\hline & & & n & $\%$ & p-value & $\mathbf{n}$ & $\%$ & p-value \\
\hline Preterm birth & & & & & 0.267 & & & 0.636 \\
\hline Yes & 6 & 9.8 & 22857 & 6.6 & & 15 & 12.2 & \\
\hline No & 55 & 90.2 & 337409 & 93.4 & & 108 & 87.8 & \\
\hline Born SGA & & & & & 0.056 & & & 0.185 \\
\hline Yes & 4 & 6.6 & 9465 & 2.6 & & 3 & 2.5 & \\
\hline No & 57 & 93.4 & 349393 & 97.4 & & 116 & 97.5 & \\
\hline Low birth weight & & & & & 0.037 & & & 0.699 \\
\hline Yes & 6 & 9.8 & 15919 & 4.4 & & 10 & 8.1 & \\
\hline No & 55 & 90.2 & 347745 & 95.6 & & 113 & 91.9 & \\
\hline Instrumental delivery & & & & & 0.68 & & & 0.586 \\
\hline Yes & 7 & 11.5 & 48349 & 13.3 & & 11 & 8.9 & \\
\hline No & 54 & 88.5 & 316145 & 86.7 & & 112 & 91.1 & \\
\hline Cesarean section & & & & & 0.001 & & & 0.079 \\
\hline Yes & 19 & 31.1 & 58637 & 16.1 & & 24 & 19.5 & \\
\hline No & 42 & 68.9 & 305855 & 83.9 & & 99 & 80.5 & \\
\hline
\end{tabular}




\section{Specific results in Paper IV: Long-term cardiovascular outcomes after childbirth}

In the 57 women with Marfan syndrome who had given birth between 1995 and 2010, cardiovascular diagnoses during or after pregnancy were found in 11 cases (19.3\%). These women were born between 1973 and 1981. Women with Marfan syndrome who had given birth, but did not have a cardiovascular diagnosis were born between 1973 and 1993. The mean age at pregnancy of all women in this study was 27.8 years, SD 4.57 .

The median follow-up time after childbirth was 6 years (3-18) and the follow-up time did not differ in women with Marfan syndrome with or without cardiovascular diagnoses.

The diagnosis of Marfan syndrome was set prior to pregnancy in all women with Marfan syndrome who had given birth and had at least one cardiovascular diagnosis after childbirth.

Cardiovascular diagnoses were also recorded in the NPR for 26 women $(12.0 \%)$ with Marfan syndrome who had not given birth.

In the group of women who did not have Marfan syndrome, one woman had a diagnosis of hypertension after childbirth, and one had experienced pacemaker implantation, but no diagnosis of cardiac arrhythmia was found in the register. In another woman, a diagnosis of surgical valve repair was found, but no diagnosis of valvular heart disease.

The distribution of the cardiovascular diagnoses in women with Marfan syndrome is presented in Table 4.

The frequencies in aortic dissection corresponded in the group of women with Marfan and pregnancy and the group of women with Marfan syndrome without pregnancy, $3.5 \%$ and $4.1 \%$ respectively $(\mathrm{p}=1.00)$.

Cardiac arrhythmia was the most common adverse cardiovascular outcome in women with Marfan syndrome after childbirth. The frequencies of the diagnoses in women with Marfan syndrome and pregnancy were more than double compared to women with Marfan syndrome without pregnancy, $12.3 \%$ and $5.1 \%$ respectively $(\mathrm{p}=0.071)$. One woman with Marfan syndrome had a complete atrioventricular block prior to pregnancy, which led to pacemaker implantation. One woman with Marfan syndrome received a pacemaker because 
of atrioventricular block after childbirth and another woman had an ICD implanted after ventricular tachycardia after childbirth. Three women with Marfan syndrome without pregnancy also had a device implanted.

The frequencies of valvular heart disease were also almost doubled, 7.0\% in women with Marfan syndrome and pregnancy and $4.2 \%$ in women with Marfan syndrome without pregnancy $(\mathrm{p}=0.483)$. Three women with Marfan syndrome underwent surgical valvular replacement after childbirth $(5.3 \%)$, and two women with Marfan syndrome without pregnancy also had valvular replacement $(0.9 \%)(\mathrm{p}=0.197)$.

\begin{tabular}{|lccr|}
\hline \multicolumn{4}{|c|}{ Table 4. Cardiovascular diagnoses in women with Marfan syndrome after childbirth $^{a}$} \\
\hline & $\begin{array}{c}\text { Marfan syndrome } \\
\text { with children } \\
(\mathrm{n}=57)\end{array}$ & $\begin{array}{c}\text { Marfan syndrome } \\
\text { no children } \\
(\mathrm{n}=216)\end{array}$ & \\
Fisher's exact test & $\mathbf{n}(\mathbf{\%})$ & $\mathbf{n}(\mathbf{\%})$ & p-value \\
\hline Aortic dissection & $2(3.5)$ & $9(4.1)$ & 1.000 \\
Aortic aneurysm ruptured & $2(3.5)$ & $2(0.9)$ & 0.283 \\
Aortic aneurysm not ruptured & $4(7.0)$ & $10(4.6)$ & 0.503 \\
Cardiac arrhythmia & $7(12.3)$ & $11(5.1)$ & 0.071 \\
Valvular heart disease & $4(7.0)$ & $9(4.2)$ & 0.483 \\
Hypertension & $2(3.5)$ & $7(3.2)$ & 1.000 \\
\hline Total no of diagnoses found & $\mathbf{2 1}$ & $\mathbf{4 8}$ \\
\hline
\end{tabular}

${ }^{\mathrm{a}}$ Women may have more than one diagnosis. 


\section{General discussion}

\section{Discussion of the methodology}

All types of study design have specific advantages and disadvantages.

The studies in this thesis are based on data from population-based registers.

This is an advantage in investigating rare medical conditions such as CHD and Marfan syndrome, since the study population is large, and sometimes the whole population of a country can be included. This means larger numbers of cases can be analyzed in each group, which is difficult to achieve using clinical data in this specific setting.

However, it is important to remember that when large data sets are used, a large sample size may give statistically significant results even when there are very small differences between the compared groups. When groups of different sample sizes are investigated, the same problem may arise with statistical significance. It is important to choose an appropriate statistical analysis in these cases and to take a considered approach when interpreting the results.

There is no risk of selection bias in Papers I and II or in the cohort study in Paper III, since the whole population is included and investigated. However, there may be confounding, due to large unobserved differences in characteristics of the study participants. In the multiple logistic regression analysis in Papers I and II, we tried to control characteristics known to cause confounding and therefore reduce this, but it is not possible to eliminate the risk entirely. In the cohort study in Paper III, the group of individuals with Marfan syndrome was so small that it was impossible to conduct multivariate analysis. This is a known problem with small sample sizes, and particularly poses a problem when the predictors are categorical or there is a limited number of cases in each category. We therefore chose to conduct a case-control study in Paper III, and matched the controls by age and delivery year to increase the validity of the results.

A number of considerations have to be taken into account in conducting studies on rare conditions such as Marfan syndrome. Case-control studies are 
particularly appropriate for examining rare conditions where data are hard to obtain. However, there are disadvantages with the study design.

If the exposure studied is rare, the study design is inefficient, and in casecontrol studies there is always a risk of selection bias when choosing controls. An important way of avoiding this is to ensure that the choice of controls is causal. A problem with bias may occur if controls do not wish to take part in the study or if they are not representative. Swedish population-based registers provide an opportunity to choose controls from a large source population, which enables higher quality case-control studies to be conducted.

A technique for adding power to a study is to enroll more than one control for each case. We chose two controls per case since, for statistical reasons, little is gained by including more than two controls. In addition, the more controls there are, the greater the risk of a skewed distribution of the controls. Matching was only by age and delivery year, to avoid overmatching.

In the study on cardiovascular outcomes in women with Marfan syndrome after childbirth some consideration must be given to the diversity in the group of women with Marfan syndrome who did not give birth. This group most probably consists women with severe forms of Marfan syndrome. These women are often advised against pregnancy. This group also includes women that are young and were probably not yet planning to become pregnant.

When using population-based register data, it is very important to be aware of the quality of the specific data used in the studies. There could always be inadequate data, even if the registers are validated. For example, a problem with the data from the MBR is that there are measurement errors in birth weights, specifically among individuals with extremely low or extremely high birth weights ${ }^{85,86}$. This is the reason why we excluded from our study population individuals with extremely low or high birth weight with respect to the gestational length.

Other considerations concerning the data registered in the MBR is that there is no information on ultrasound examinations during pregnancy in the register, and the MBR only has information on the children from the neonatal period. It is difficult to detect cardiac malformations during pregnancy, even with new ultrasound techniques. Only about $30 \%$ of all congenital malformations of the heart and the great vessels are found during pregnancy ${ }^{13,93}$. Highly specialized 
units report detection rates of approximately $50 \%{ }^{13}$. It is also common to find that congenital cardiac malformations are not diagnosed during the neonatal period. During the last few years, new guidelines have been introduced to detect duct-dependent lesions with the use of pulse oximetry in the first days after birth, which has increased the detected rates of heart malformations ${ }^{94}$. However, this routine has only been in use for some years in Sweden, and the children investigated in our studies have not benefitted from these new guidelines. The consequence is that the number of children with a detected malformation is most probably under-reported in our studies.

Malformations of the heart are diverse, which may cause a problem when the malformations are categorized. Even the same malformation can have a very different manifestation in different individuals ${ }^{63}$. This makes it difficult to generalize about the risks associated with the different heart malformations and to draw valid conclusions, even where other study designs are used.

When every diagnosis of CHD is analyzed separately, the number of cases in the groups becomes rather small, since there are many different malformations. Studies often divide diagnoses into groups, as this provides larger group sizes. We chose to divide the malformations into simple and complex, based on an anatomical approach. No differences were found in our analyses between "simple CHD" and "complex CHD", and there were significantly higher risks of adverse outcomes for both groups compared to the group without CHD. They could also have been divided into groups by clinical severity. This would have given us three groups of CHD (Figure 2). The results might have differed between the subgroups due to the different clinical severity of the groups compared, or the results could have corresponded with the results in Paper I. Whatever the results, this would have been more useful information for obstetricians treating women with CHD during pregnancy.

A drawback in the studies on Marfan syndrome is that no information on aortic diameter is given in the NPR, and also the severity of aortic aneurysm and valvular heart disease cannot be determined from the diagnosis in the register.

Previous studies on the obstetric and neonatal outcomes of pregnancy in women with both CHD and Marfan syndrome have mixed primi- and multiparous women in the analyses, and have also often used repeated measures in the women, i.e. each pregnancy in one woman was counted as an individual 
case $^{62,66,67}$. To avoid the confounding that this causes, we have chosen to investigate the women's first pregnancy. Previous studies have shown that if adverse outcomes such as preterm birth, SGA or cesarean section occur in the first pregnancy of a woman the risk is increased in further pregnancies ${ }^{82,83}$.

The studies in this thesis are observational studies, in which an event affects subjects with a specific condition and is recorded in registries without predefined treatment for the subjects. The observational design is a major drawback because it makes causal interpretation impossible. The studies can only be used to describe the population and to formulate hypotheses. Nevertheless, this is important in studying new patient groups. Women with CHD and Marfan syndrome were previously often advised against pregnancy due to the risks it might have posed. Today, women with CHD and Marfan syndrome represent a growing group of patients for obstetricians. It is important to acquire knowledge about pregnancy-related outcomes in this group of women in an effort to reduce the risks associated with pregnancy. 


\section{Discussion of the results}

\section{Papers I and II: Women and men with CHD}

\section{Birth characteristics}

Women and men with CHD were more likely to be born preterm, SGA and delivered by cesarean section than individuals with no diagnosis of CHD. This is in accordance with earlier findings ${ }^{95}$. The fact that the results from Paper I were reproduced in Paper II add strength to the results. Men with CHD were also more likely to be born LGA, which was surprising, but all results can be explained as the consequence of a high-risk pregnancy.

The likelihood of individuals with CHD giving birth has not been previously investigated. Women with CHD had lower birth rates than women not diagnosed with CHD. In a further analysis, with adjustments made for sociodemographic characteristics, they were more likely to give birth during the study period, and they were also younger at the time of their first pregnancy compared to the general population. Men were less likely to become fathers. The result for the women may be explained by recommendations from cardiologists; many women with CHD are advised not to wait too long before becoming pregnant, as it may affect their cardiac function.

\section{Outcomes of pregnancy}

Previous studies on the outcomes of pregnancy in women with CHD show that there are increased risks of preterm birth, SGA, low birth weight and recurrence of CHD in their children compared to children of women without CHD. The children of women with CHD are also more often delivered by cesarean section. The results from our study are in accordance with previous findings ${ }^{61,63,96}$.

We found increased risks of malformation in the children of women with CHD compared to children of women without CHD. No difference was found in children of women with simple CHD compared to children of women with complex CHD. Previous studies have investigated the risk of cardiac malformation and reported recurrence rates of $2-20 \%$. The risks are dependent on the specific type of CHD, as the pattern of inheritance differs between the different malformations ${ }^{15,23}$. In our study, we investigated the risk of any 
malformation in the children of women with CHD. We did not investigate the proportion of the total malformations, which were cardiac.

The children of men with CHD had no increased risk of adverse obstetric or neonatal outcomes compared to children of men with no CHD diagnosis. To our knowledge, this is the first study to investigate outcomes in children of men with CHD. We also found no increased risks of malformation in children of men with CHD. Prior studies have shown an increased risk of CHD of approximately $2-4 \%$ in the offspring ${ }^{24}$. However, these studies are based on a small series of specific heart malformations. Our results may be due to underreporting of malformations since we only have data from the MBR on the children of individuals with CHD, but the fact that we nevertheless found increased neonatal risks suggests that the children of men with $\mathrm{CHD}$ are not at high risk.

\section{Papers III and IV: Marfan syndrome}

\section{Birth characteristics}

The parental socio-demographic characteristics of women with Marfan syndrome did not differ from those of women who did not have the condition. Women with Marfan syndrome were more likely to be born preterm, SGA, with a birth weight below 2500 grams and by cesarean section than women with no diagnosis of Marfan syndrome. The results were repeated in the cohort analysis and the case-control analysis.

The results are in accordance with previous studies on the outcomes of children with congenital malformations and syndromes and indicate that pregnancies with known fetal malformations or syndromes need to be carefully monitored ${ }^{95}$.

\section{Outcomes of pregnancy}

Women with Marfan syndrome were less likely to give birth than women without Marfan syndrome, which may be due to medical problems related to the condition.

In our study, no statistically increased neonatal risks such as preterm birth, low birth weight, SGA or LGA, were found in the children of women with Marfan 
syndrome. In the cohort analysis children of women with Marfan syndrome were more likely to have been born with a birth weight below 2500 grams.

There is an inconsistency in previous results on obstetric and neonatal outcomes in women with Marfan syndrome. A possible explanation is that previous studies dealt with small numbers of pregnancies, and that the studies were conducted between 1981 and 2015 $5^{50,66-68,76,78,97}$. Another explanation is that most studies have used repeated measures in their analyses, since each pregnancy in one woman is calculated separately ${ }^{50,66,67,76,78,97}$. A third reason for the low risk of obstetrical and neonatal complications may be better clinical management due to greater awareness of the risks that pregnancy poses for women with the condition.

In a study from 1981, Pyeritz et al. described an increased risk of preterm birth $^{97}$. Rossiter et al. performed the first prospective study on pregnancy in women with Marfan syndrome in 1995. They followed 21 women over ten years, and did not find any increased risks of adverse obstetric or neonatal outcomes $^{50}$. Meijboom et al. reported no increased risk of SGA in 2005. However, they found an increased risk of preterm birth ${ }^{67}$. A French study by Omnes et al. (2013) reported a high risk for preterm birth and SGA ${ }^{78}$. Donnelly et al. found no increased risk of preterm birth or SGA in $2012^{52}$. Curry et al. (2014) reported an increased risk of SGA, but no increased risk of preterm birth $^{68}$. A Canadian study by Hassan et al. in 2015 reported a higher risk of preterm birth and SGA in children of women with Marfan syndrome compared to children of women without the condition ${ }^{66}$.

Cesarean section is often performed where there is concern for maternal health due to growing aortic diameter ${ }^{98}$. A cesarean section was performed in $31.1 \%$ of the women with Marfan syndrome compared to $19.5 \%$ of the controls and in $16.1 \%$ of the cohort. In the case-control study there was no statistically significant difference, but in the cohort analysis the difference was significant. Cesarean section rates have varied greatly in previous studies (8-77\%), probably due to the small sample sizes, different management in different countries, a variety of hospitals managing patients with different severity of the condition and the time span of the published studies (1981-2015) $)^{50,68,78,97}$.

In most previous studies, cesarean section rates have also been evaluated without taking the parity of the women into account, or the increased risk of 
cesarean section after a previous cesarean section, which is an important known confounder ${ }^{50,66,67,76,78}$.

\section{Long-term outcomes of cardiovascular disease after childbirth}

To our knowledge, the long-term outcomes of cardiovascular status in women with Marfan syndrome have only been described in three previous studies ${ }^{50-52}$.

The main concern of cardiologists has been the risk of aortic growth and aortic dissection in women with Marfan syndrome, both during pregnancy and in the long-term follow-up, which has been the focus of previous studies. In all studies, women with Marfan syndrome were followed for approximately 6 years, and aortic diameters and aortic dissections were reported.

In an American study from 1995, 18 women were followed after childbirth using ultrasound examinations. No increased risks of aortic complications were found compared to women with Marfan syndrome who did not give birth ${ }^{50}$. Ten years later, a Dutch study described aortic diameters in 23 women during pregnancy. Increased aortic diameter after childbirth was found in nine women with an aorta diameter of $\geq 40 \mathrm{~mm}$ prior to pregnancy compared to matched childless controls. No increased risks were found women with an aortic diameter of $\leq 40 \mathrm{~mm}$ before pregnancy ${ }^{51}$.

The most recent study evaluated risk factors for adverse cardiovascular outcomes after childbirth. Multiple pregnancies, larger aortic diameter prior to pregnancy, growing diameter of the aorta during pregnancy and lack of betablocker use were detected as risk factors. They also reported increasing diameters of the aorta after pregnancy that did not return to pre-pregnancy values after childbirth ${ }^{52}$.

No data on aortic diameter are recorded in the population-based registers. We have a similar follow-up period, and the rates of aortic dissection during pregnancy correlate with the frequencies in previous studies. The two women experiencing aortic dissection were at increased risk, and had a thoracic aortic aneurysm prior to pregnancy.

To our knowledge, there are no previous studies investigating all cardiovascular diagnoses and cardiac surgical procedures in women with Marfan syndrome after childbirth, even if the features of Marfan syndrome also include valvular heart disease and cardiac arrhythmia. 
The results showed higher frequencies of cardiovascular disease after childbirth since cardiovascular diagnoses were found in 11 (19.3\%) of the 57 women who had given birth compared to 26 women (12.0\%) of the 216 women who had not given birth.

A common complication during normal pregnancy is cardiac arrhythmia, and studies indicate that as many as $15 \%$ of all pregnant women may be affected $^{99,100}$. However, most arrhythmias in healthy women during pregnancy do not require any medical treatment ${ }^{101,102}$. In our group of controls without Marfan syndrome no case of cardiac arrhythmia was found. This result is somewhat surprising, but may be a consequence of the low number of individuals studied and that arrhythmia could be under-diagnosed during pregnancy in our population since most cases do not require medical treatment. Marfan syndrome is associated with different types of arrhythmia due to the affected fibrillin network in the myocardium, and the presence of mitral and tricuspid valve prolapse $e^{47,103,104}$. Increased risk of Wolff-Parkinson-White syndrome and atrial fibrillation has been described. Ventricular arrhythmias may also occur with the risk of sudden death ${ }^{47}$. The specific diagnoses of cardiac arrhythmia in our series correspond to previously described diagnoses in individuals with Marfan syndrome ${ }^{47}$.

The frequency of valvular heart disease was also almost doubled after childbirth even if the exact numbers were small.

Of the women with Marfan syndrome and pregnancy, three (5.3\%) underwent surgical valve replacement after childbirth, as did two $(0.9 \%)$ of the women with Marfan syndrome without pregnancy. This could indicate that valvular heart disease in women with Marfan syndrome is worsened by pregnancy. The result could also explain the higher frequencies of arrhythmia in women with Marfan syndrome after childbirth in our study, as mitral and tricuspid valve insufficiency is associated with cardiac arrhythmia ${ }^{103,104}$.

A possible explanation of complications is the effect of cardiac modulation and growth of the heart on the impaired fibrillin structures during pregnancy.

We found lower rates of aortic aneurysm and valvular heart disease in women with Marfan syndrome than expected. A possible explanation may be that women with Marfan syndrome who undergo pregnancy have milder forms of the condition. Another reason may be that individuals with Marfan syndrome only receive the diagnosis of Marfan syndrome in the register since aortic 
aneurysm and also valvular heart disease are criteria for the diagnosis of Marfan syndrome.

Even with higher frequencies of cardiovascular diagnoses observed in women with Marfan syndrome after childbirth, the results were not statistically significant. 


\section{Future research}

In this thesis, the studies have had a limited follow-up time with respect to reproductive age. In the studies on $\mathrm{CHD}$, the oldest individuals were 33 years old in 2006 when the study period ended. In order to study the effect of CHD on reproduction and the affected women's health throughout their life span, new studies will be necessary.

It would also be of value to perform studies where the different types of CHD are grouped with respect to clinical severity.

There are still considerable gaps in knowledge in terms of small, specific groups of women with CHD, e.g. women with Fontan circulation are a "new" group of women, since this surgical correction has only been performed since the 1990s. This group needs to be followed prospectively.

There are few studies on the recurrence rates of CHD, and on whether there is an association with other malformations in the children of individuals with CHD. This is an important question for obstetricians working in fetal medicine. It may be possible to investigate this using Swedish register data.

Marfan syndrome is a rare disease for which obstetric and neonatal outcomes of pregnancy and long-term cardiovascular outcomes after childbirth remain uncertain. It would be interesting to follow outcomes throughout the lifespan of subjects as many complications occur later in life. 


\section{Conclusions}

- Women and men with CHD are more likely to be born preterm, SGA and delivered by cesarean section.

- There is a higher risk of preterm birth and SGA in children of women with CHD. The children also run a higher risk of congenital malformations. The children of women with CHD are more often delivered by cesarean section than those of women without CHD.

- Children of men with CHD had no increased risk of adverse obstetric and neonatal outcomes.

- Women with Marfan syndrome were more often born preterm, SGA and by cesarean section than women without the condition. There was no increased risk of children of women with Marfan syndrome being born preterm, SGA or by cesarean section. 


\section{Populärvetenskaplig sammanfattning}

De medicinska framstegen de senaste decennierna har lett till att kvinnor med allvarliga sjukdomar som påverkar hjärt-kärlsystemet har större förutsättningar att kunna genomgå graviditet. Många av dem upplever inte att de är sjuka på grund av att de genomgått korrigerande kirurgi vid tidig ålder och därefter inte behövt medicinera, eller så medicinerar de och är väl inställda på sin medicinering vilket leder till att de har god fysisk förmåga och livskvalité.

Graviditet innebär dock en mycket stor belastning för hjärt-kärlsystemet och framförallt hjärtat. Blodvolymen ökar under graviditet med cirka 1,5 liter, pulsen ökar med cirka 20 slag per minut vilket innebär att hjärtat måste öka sitt arbete med nästan $50 \%$.

Studierna i den här avhandlingen fokuserar på två olika typer av åkommor som påverkar hjärtkärlsystemet. Medfödd missbildning i hjärtat och/eller kärlsystemet är den vanligaste typen av missbildning som drabbar ungefär en procent av befolkningen. Det kan handla om icke slutna väggar inom hjärtat eller problem med de så kallade hjärtklaffarna, som är dörrarna mellan rummen i hjärtat. Det kan finnas en förträngning eller en otillräcklig stängning av klaffarna vilket leder till att blodet antingen har svårt att ta sig ut ur hjärtrummet eller strömmar tillbaka in i det rummet som det kom ifrån. Utöver dessa problem kan det vara mer komplexa problem som felkopplingar mellan kärl eller en kombination av avvikelser.

Marfans syndrom är en ärftlig medfödd bindvävssjukdom som påverkar flera organsystem i kroppen. De vanligaste problemen uppstår i hjärtat, kärlen, ögonen, skelettet och lederna. De allvarligaste komplikationerna drabbar hjärtkärlsystemet. I hjärtat innehåller klaffarna mycket bindväv vilket kan leda till att de stänger otillräckligt vid det här syndromet. Även de stora kärlen är påverkade och då ofta vidgade.

Hur graviditet påverkar individer med de här tillstånden och deras barn är otillräckligt undersökt. Tidigare avrådde man ofta kvinnor med hjärtmissbildning och Marfans syndrom från att bli gravida på grund av riskerna det innebär för den blivande modern och det väntade barnet. 
Syftet med den här avhandlingen är att öka förståelsen för hur graviditet hos dessa kvinnor påverkar riskerna för dem själva och deras barn, men även hur det går för barnen till män med hjärtmissbildning och hur hjärtat påverkas hos kvinnor med Marfans syndrom efter graviditet. Vi har även undersökt sociodemografiska egenskaper hos individerna och utfall i samband med deras egen födelse. I Sverige samlas information om populationen i kvalitetsregister som sköts av Statistiska Centralbyrån och Socialstyrelsen. För att besvara våra frågor inhämtades anonymiserade persondata från registren.

I delstudie I och II omfattades alla svenska kvinnor och män som fått en diagnos för hjärtmissbildning och som var födda 1973-1983. Det motsvarar ca 5000 kvinnor och män. I delstudie III och IV omfattar alla svenska kvinnor med Marfans syndrom födda 1973-1993 vilket motsvarar 273 kvinnor.

Studierna visade att män och kvinnor med hjärtmissbildning och kvinnor med Marfans syndrom oftare föddes för tidigt, med låg födelsevikt eller liten-förtiden. De föddes även oftare med kejsarsnitt.

Vi undersökte även utfallet av deras första egna förlossning.

Barn till kvinnor med hjärtmissbildning hade samma risker som sina mödrar, det vill säga de föddes oftare för tidigt, med låg födelsevikt eller liten-för tiden och med kejsarsnitt. Barnen hade en högre sannolikhet att vara drabbade av medfödda missbildningar. Kvinnor med hjärtmissbildning var yngre när de födde sitt första barn och de hade en större sannolikhet att bli mamma under studieperioden.

Avseende män med hjärtmissbildning så drabbades deras barn inte oftare av komplikationer i samband med födseln jämfört med barn till män som inte har hjärtmissbildning. Männen hade lägre sannolikhet att bli fäder än män utan hjärtmissbildning under studieperioden.

I studierna som undersöker graviditet hos kvinnor med Marfans syndrom fann vi inga statistiska skillnader i utfallet av deras barn.

Vi fann även en högre frekvenser av hjärtarytmier och sjukdomar i hjärtklaffarna hos kvinnor med Marfans syndrom som fött barn än hos kvinnor som har Marfans syndrom men inte fött barn. Resultatet är dock inte statistiskt säkerhetsställt. 
Eftersom det här är en växande grupp av vuxna individer som har önskan att bli föräldrar är det viktigt att fortsätta studera hur graviditet påverkar dem och deras barn för att förbättra omhändertagandet i samband med graviditet och förlossning. 


\section{Acknowledgements}

I would like to thank all of you who helped and supported me during this project, and especially:

Professor Ann Josefsson, my main supervisor, for your enthusiasm and your continuous encouragement throughout the work with this thesis. Your advice on both research, as well as my clinical work, has been invaluable.

Professor Gunilla Sydsjö for your guidance and valuable comments, and for sharing some of your knowledge with me. You have helped me to keep a clear mind when I have doubted.

Dr Niels Erik Nielsen for introducing me to the field of congenital heart disease and for your words of encouragement and guidance when I tried to understand cardiac malformations and their severity.

Marie Bladh, for our stimulating discussions about research and life in general, for your patience with my statistical efforts and for always being there when I needed someone to talk to.

Dr Ninnie Borendal Wodlin, head of the Department of Obstetrics and Gynecology, University Hospital in Linköping, for giving me the time and opportunity to complete this thesis.

Senior Professor Göran Berg, Professor Preben Kjölhede, Associate Professor Ulf Samuelsson, Dr Caroline Lilliecreutz, Associate Professor Marie Blomberg, and Dr Marcus Lindenberger for taking the time to review my thesis and manuscripts and contributing with valuable opinions.

All my friends and colleagues at the Department of Obstetrics and Gynecology at the University Hospital in Linköping for your support. 
Dr Maria Sarberg. Our friendship is invaluable to me, and I never could have done this without you.

Helena Larson, for taking care of Ungaro when I was ill, pregnant and working on this thesis, and for being my friend. Leena Larson, for your support, especially in caring for our children, has been invaluable.

My mother, Ulla, for always being there, helping us with the children, and for your never-ending love and support.

Jörg, the love of my life and my best friend, and our children Vilhelm and Klara, the most important people in my world. For your love and for believing in me. 


\section{References}

1. Adams JN, Trent RJ. Aortic complications of Marfan's syndrome. Lancet 1998;352:1722-3.

2. Mahendru AA, Everett TR, Wilkinson IB, Lees CC, McEniery CM. A longitudinal study of maternal cardiovascular function from preconception to the postpartum period. $\mathrm{J}$ Hypertens 2014;32:849-56.

3. Sanghavi M, Rutherford JD. Cardiovascular physiology of pregnancy. Circulation 2014;130:1003-8.

4. Abbas AE, Lester SJ, Connolly H. Pregnancy and the cardiovascular system. Int J Cardiol 2005;98:179-89.

5. Kampman MA, Valente MA, van Melle JP, et al. Cardiac adaption during pregnancy in women with congenital heart disease and healthy women. Heart 2016;102:1302-8.

6. Robson SC, Hunter S, Boys RJ, Dunlop W. Serial study of factors influencing changes in cardiac output during human pregnancy. Am J Physiol 1989;256:H1060-5.

7. Warnes CA. Pregnancy and Delivery in Women With Congenital Heart Disease. Circ J 2015;79:1416-21.

8. Beral V. Long term effects of childbearing on health. J Epidemiol Community Health 1985;39:343-6.

9. Ness RB, Harris T, Cobb J, et al. Number of pregnancies and the subsequent risk of cardiovascular disease. N Engl J Med 1993;328:1528-33.

10. Green A, Beral V, Moser K. Mortality in women in relation to their childbearing history. BMJ (Clinical research ed) 1988;297:391-5.

11. Humphries KH, Westendorp IC, Bots ML, et al. Parity and carotid artery atherosclerosis in elderly women: The Rotterdam Study. Stroke 2001;32:2259-64.

12. Libby P, Bonow RO, Mann DL, Zipes DP. Braunwald's Heart Disease: A textbook of Cardiovascular Medicine. Eighth Edition: Saunders; 2008. p1561-1624.

13. Sharland G. Fetal cardiac screening and variation in prenatal detection rates of congenital heart disease: why bother with screening at all? Future Cardiol 2012;8:189-202.

14. Saettele AK, Christensen JL, Chilson KL, Murray DJ. Children with heart disease: Risk stratification for non-cardiac surgery. J Clin Anesth 2016;35:479-84.

15. Roos-Hesselink JW, Kerstjens-Frederikse WS, Meijboom FJ, Pieper PG. Inheritance of congenital heart disease. Neth Heart J 2005;13:88-91.

16. Raymond FL, Simpson JM, Sharland GK, Ogilvie Mackie CM. Fetal echocardiography as a predictor of chromosomal abnormality. Lancet 1997;350:930.

17. Blue GM, Kirk EP, Sholler GF, Harvey RP, Winlaw DS. Congenital heart disease: current knowledge about causes and inheritance. Med J Aust 2012;197:155-9.

18. Wren C, Birrell G, Hawthorne G. Cardiovascular malformations in infants of diabetic mothers. Heart 2003;89:1217-20.

19. Oster ME, Riehle-Colarusso T, Correa A. An update on cardiovascular malformations in congenital rubella syndrome. Birth Defects Res A Clin Mol Teratol 2010;88:1-8.

20. Vecoli C, Pulignani S, Foffa I, Andreassi MG. Congenital heart disease: the crossroads of genetics, epigenetics and environment. Current genomics 2014;15:390-9.

21. Wurst KE, Poole C, Ephross SA, Olshan AF. First trimester paroxetine use and the prevalence of congenital, specifically cardiac, defects: a meta-analysis of epidemiological studies. Birth Defects Res A Clin Mol Teratol 2010;88:159-70.

22. Soufia M, Aoun J, Gorsane MA, Krebs MO. [SSRIs and pregnancy: a review of the literature]. Encephale 2010;36:513-6. 
23. Nora JJ, Nora AH. Recurrence risks in children having one parent with a congenital heart disease. Circulation 1976;53:701-2.

24. Nora JJ, Nora AH. Update on counseling the family with a first-degree relative with a congenital heart defect. Am J Med Genet 1988;29:137-42.

25. Driscoll DJ, Michels VV, Gersony WM, et al. Occurrence risk for congenital heart defects in relatives of patients with aortic stenosis, pulmonary stenosis, or ventricular septal defect. Circulation 1993;87:I114-20.

26. Romano-Zelekha O, Hirsh R, Blieden L, Green M, Shohat T. The risk for congenital heart defects in offspring of individuals with congenital heart defects. Clin Genet 2001;59:325-9.

27. Harris IS. Management of pregnancy in patients with congenital heart disease. Prog Cardiovasc Dis 2011;53:305-11.

28. Hoffman JI, Kaplan S, Liberthson RR. Prevalence of congenital heart disease. Am Heart J 2004;147:425-39.

29. Simoni G, Brambati B, Danesino C, et al. Efficient direct chromosome analyses and enzyme determinations from chorionic villi samples in the first trimester of pregnancy. Hum Genet 1983;63:349-57.

30. Stoney WS. Evolution of cardiopulmonary bypass. Circulation 2009;119:2844-53.

31. Heymann MA, Clyman RI. Evaluation of alprostadil (prostaglandin E1) in the management of congenital heart disease in infancy. Pharmacotherapy 1982;2:148-55.

32. Loomba RS, Buelow MW, Aggarwal S, Arora RR, Kovach J, Ginde S. Arrhythmias in Adults with Congenital Heart Disease: What are Risk Factors for Specific Arrhythmias? Pacing Clin Electrophysiol 2016.

33. Cuypers JA, Utens EM, Roos-Hesselink JW. Health in adults with congenital heart disease. Maturitas 2016;91:69-73.

34. Gabriels C, De Backer J, Pasquet A, et al. Long-Term Outcome of Patients with Perimembranous Ventricular Septal Defect: Results from the Belgian Registry on Adult Congenital Heart Disease. Cardiology 2016;136:147-55.

35. Balint $\mathrm{OH}$, Siu SC, Mason J, et al. Cardiac outcomes after pregnancy in women with congenital heart disease. Heart 2010;96:1656-61.

36. Kampman MA, Balci A, Groen H, et al. Cardiac function and cardiac events 1-year postpartum in women with congenital heart disease. Am Heart J 2015;169:298-304.

37. Bowater SE, Selman TJ, Hudsmith LE, Clift PF, Thompson PJ, Thorne SA. Longterm outcome following pregnancy in women with a systemic right ventricle: is the deterioration due to pregnancy or a consequence of time? Congenit Heart Dis 2013;8:302-7. 38. Judge DP, Dietz HC. Marfan's syndrome. Lancet 2005;366:1965-76.

39. Pyeritz RE. Recent progress in understanding the natural and clinical histories of the Marfan syndrome. Trends Cardiovasc Med 2016;26:423-8.

40. Loeys BL, Dietz HC, Braverman AC, et al. The revised Ghent nosology for the Marfan syndrome. J Med Genet 2010;47:476-85.

41. Pyeritz RE. The Marfan syndrome. Annu Rev Med 2000;51:481-510.

42. Dietz HC, Cutting GR, Pyeritz RE, et al. Marfan syndrome caused by a recurrent de novo missense mutation in the fibrillin gene. Nature 1991;352:337-9.

43. Keane MG, Pyeritz RE. Medical management of Marfan syndrome. Circulation 2008;117:2802-13.

44. Murdoch JL, Walker BA, Halpern BL, Kuzma JW, McKusick VA. Life expectancy and causes of death in the Marfan syndrome. N Engl J Med 1972;286:804-8.

45. Silverman DI, Burton KJ, Gray J, et al. Life expectancy in the Marfan syndrome. Am J Cardiol 1995;75:157-60. 
46. Wanga S, Silversides C, Dore A, de Waard V, Mulder B. Pregnancy and Thoracic Aortic Disease: Managing the Risks. Can J Cardiol 2016;32:78-85.

47. Stuart AG, Williams A. Marfan's syndrome and the heart. Arch Dis Child 2007;92:351-6.

48. Yetman AT, Bornemeier RA, McCrindle BW. Usefulness of enalapril versus propranolol or atenolol for prevention of aortic dilation in patients with the Marfan syndrome. Am J Cardiol 2005;95:1125-7.

49. Bons LR, Roos-Hesselink JW. Aortic disease and pregnancy. Curr Opin Cardiol 2016;31:611-7.

50. Rossiter JP, Repke JT, Morales AJ, Murphy EA, Pyeritz RE. A prospective longitudinal evaluation of pregnancy in the Marfan syndrome. Am J Obstet Gynecol 1995;173:1599-606.

51. Meijboom LJ, Vos FE, Timmermans J, Boers GH, Zwinderman AH, Mulder BJ. Pregnancy and aortic root growth in the Marfan syndrome: a prospective study. Eur Heart $\mathrm{J}$ 2005;26:914-20.

52. Donnelly RT, Pinto NM, Kocolas I, Yetman AT. The immediate and long-term impact of pregnancy on aortic growth rate and mortality in women with Marfan syndrome. $\mathrm{J}$ Am Coll Cardiol 2012;60:224-9.

53. Blencowe H, Cousens S, Oestergaard MZ, et al. National, regional, and worldwide estimates of preterm birth rates in the year 2010 with time trends since 1990 for selected countries: a systematic analysis and implications. Lancet 2012;379:2162-72.

54. Tucker J, McGuire W. Epidemiology of preterm birth. BMJ (Clinical research ed) 2004;329:675-8.

55. Taylor HG. Outcomes of preterm birth: a lifespan perspective. Dev Med Child Neurol 2017.

56. Darlow BA, Horwood LJ, Woodward LJ, et al. The New Zealand 1986 very low birth weight cohort as young adults: mapping the road ahead. BMC Pediatr 2015;15:90.

57. Gardosi J, Kady SM, McGeown P, Francis A, Tonks A. Classification of stillbirth by relevant condition at death $(\mathrm{ReCoDe})$ : population based cohort study. BMJ (Clinical research ed) 2005;331:1113-7.

58. Froen JF, Gardosi JO, Thurmann A, Francis A, Stray-Pedersen B. Restricted fetal growth in sudden intrauterine unexplained death. Acta Obstet Gynecol Scand 2004;83:801-7. 59. Barker DJ, Osmond C, Forsen TJ, Kajantie E, Eriksson JG. Maternal and social origins of hypertension. Hypertension 2007;50:565-71.

60. Barker DJ, Gluckman PD, Godfrey KM, Harding JE, Owens JA, Robinson JS. Fetal nutrition and cardiovascular disease in adult life. Lancet 1993;341:938-41.

61. Drenthen W, Pieper PG, Roos-Hesselink JW, et al. Outcome of pregnancy in women with congenital heart disease: a literature review. J Am Coll Cardiol 2007;49:2303-11.

62. Siu SC, Colman JM, Sorensen S, et al. Adverse neonatal and cardiac outcomes are more common in pregnant women with cardiac disease. Circulation 2002;105:2179-84.

63. Lindley KJ, Conner SN, Cahill AG. Adult Congenital Heart Disease in Pregnancy. Obstet Gynecol Surv 2015;70:397-407.

64. Karamlou T, Diggs BS, McCrindle BW, Welke KF. A growing problem: maternal death and peripartum complications are higher in women with grown-up congenital heart disease. Ann Thorac Surg 2011;92:2193-8; discussion 8-9.

65. Roos-Hesselink JW, Ruys PT, Johnson MR. Pregnancy in adult congenital heart disease. Curr Cardiol Rep 2013;15:401.

66. Hassan N, Patenaude V, Oddy L, Abenhaim HA. Pregnancy outcomes in Marfan syndrome: a retrospective cohort study. Am J Perinatol 2015;30:123-30. 
67. Meijboom LJ, Drenthen W, Pieper PG, et al. Obstetric complications in Marfan syndrome. Int J Cardiol 2006;110:53-9.

68. Curry RA, Gelson E, Swan L, et al. Marfan syndrome and pregnancy: maternal and neonatal outcomes. BJOG 2014;121:610-7.

69. Michaelson-Cohen R, Elstein D, Ioscovich A, et al. Severe heart disease complicating pregnancy does not preclude a favourable pregnancy outcome: 15 years' experience in a single centre. J Obstet Gynaecol 2011;31:597-602.

70. Silversides CK, Kiess M, Beauchesne L, et al. Canadian Cardiovascular Society 2009 Consensus Conference on the management of adults with congenital heart disease: outflow tract obstruction, coarctation of the aorta, tetralogy of Fallot, Ebstein anomaly and Marfan's syndrome. Can J Cardiol 2010;26:e80-97.

71. Easterling TR, Benedetti TJ, Schmucker BC, Carlson K, Millard SP. Maternal hemodynamics and aortic diameter in normal and hypertensive pregnancies. Obstet Gynecol 1991;78:1073-7.

72. Kamel H, Roman MJ, Pitcher A, Devereux RB. Pregnancy and the Risk of Aortic Dissection or Rupture: A Cohort-Crossover Analysis. Circulation 2016;134:527-33.

73. Manalo-Estrella P, Barker AE. Histopathologic findings in human aortic media associated with pregnancy. Arch Pathol 1967;83:336-41.

74. Campisi D, Bivona A, Paterna S, Valenza M, Albiero R. Oestrogen binding sites in fresh human aortic tissue. Int J Tissue React 1987;9:393-8.

75. Pacini L, Digne F, Boumendil A, et al. Maternal complication of pregnancy in Marfan syndrome. Int J Cardiol 2009;136:156-61.

76. Lipscomb KJ, Smith JC, Clarke B, Donnai P, Harris R. Outcome of pregnancy in women with Marfan's syndrome. Br J Obstet Gynaecol 1997;104:201-6.

77. Lind J, Wallenburg HC. The Marfan syndrome and pregnancy: a retrospective study in a Dutch population. Eur J Obstet Gynecol Reprod Biol 2001;98:28-35.

78. Omnes S, Jondeau G, Detaint D, et al. Pregnancy outcomes among women with Marfan syndrome. Int J Gynaecol Obstet 2013;122:219-23.

79. Siu SC, Sermer M, Colman JM, et al. Prospective multicenter study of pregnancy outcomes in women with heart disease. Circulation 2001;104:515-21.

80. Curtis SL, Marsden-Williams J, Sullivan C, et al. Current trends in the management of heart disease in pregnancy. Int J Cardiol 2009;133:62-9.

81. Avila WS, Rossi EG, Ramires JA, et al. Pregnancy in patients with heart disease: experience with 1,000 cases. Clin Cardiol 2003;26:135-42.

82. Ekwo EE, Gosselink CA, Moawad A. Previous pregnancy outcomes and subsequent risk of preterm rupture of amniotic sac membranes. Br J Obstet Gynaecol 1993;100:536-41.

83. Voskamp BJ, Kazemier BM, Ravelli AC, Schaaf J, Mol BW, Pajkrt E. Recurrence of small-for-gestational-age pregnancy: analysis of first and subsequent singleton pregnancies in The Netherlands. Am J Obstet Gynecol 2013;208:374.e1-6.

84. Centre for Epidemiology, National Board of Health and Welfare: Statistics - Health and Medical Care, Pregnancies, Deliveries and Newborn Infants, The Swedish Medical Birth Register 1973-2013, Assisted Reproduction, treatment 1991-2012. (Accessed January 26 2017, at http://www.socialstyrelsen.se/Lists/Artikelkatalog/Attachments/19627/2014-1219.pdf.)

85. Cnattingius S, Ericson A, Gunnarskog J, Kallen B. A quality study of a medical birth registry. Scand J Soc Med 1990;18:143-8.

86. Centre for Epidemiology, National Board of Health and Welfare: The Swedish Medical Birth Register; A summary of content and quality. National Board of Health and Welfare: Stockholm, Sweden. (Accessed January 26 2017, at 
http://www.socialstyrelsen.se/Lists/Artikelkatalog/Attachments/10655/2003-112-

3_20031123.pdf.)

87. Centre for Epidemiology, National Board of Health and Welfare: In-Patient Diseases in Sweden 1988-2013. (Accessed January 26 2017, at

http://www.socialstyrelsen.se/Lists/Artikelkatalog/Attachments/19533/2014-9-34.pdf.)

88. Ludvigsson JF, Almqvist C, Bonamy AK, et al. Registers of the Swedish total

population and their use in medical research. Eur J Epidemiol 2016;31:125-36.

89. Statistics Sweden. Description of the population in Sweden 2013. Örebro, Sweden.

(Accessed January 26 2017, at

http://www.scb.se/Statistik/BE/BE0101/_dokument/BE0101_BS_2013_slutlig.pdf.)

90. Centre of Epidemiology, National Board of Health and Welfare: Causes of death

2013. Stockholm, Sweden: National Board of Health and Welfare; 2013. (Accessed January

26 2017, at http://www.socialstyrelsen.se/Lists/Artikelkatalog/Attachments/19736/2015-242.pdf.)

91. Statistics Sweden: Population and Housing Census 1970 (SOS). Part 12. Report on the planning and processing of the Population and Housing Census 1970. Stockholm, Sweden: National Central Bureau of Statistics; 1974.

92. Statistics Sweden. Educational attainment of the population 2012. (publication no. UF 37 SM 1301). Örebro, Sweden. (Accessed January 26 2017, at http://www.scb.se/Statistik/UF/UF0506/2012A01P/UF0506_2012A01P_SM_UF37SM1301. pdf.)

93. Gill HK, Splitt M, Sharland GK, Simpson JM. Patterns of recurrence of congenital heart disease: an analysis of 6,640 consecutive pregnancies evaluated by detailed fetal echocardiography. J Am Coll Cardiol 2003;42:923-9.

94. Ewer AK. Screening for Critical Congenital Heart Defects with Pulse Oximetry: Medical Aspects. Am J Perinatol 2016;33:1062-6.

95. Cedergren MI, Kallen BA. Obstetric outcome of 6346 pregnancies with infants affected by congenital heart defects. Eur J Obstet Gynecol Reprod Biol 2006;125:211-6.

96. Khairy P, Ouyang DW, Fernandes SM, Lee-Parritz A, Economy KE, Landzberg MJ. Pregnancy outcomes in women with congenital heart disease. Circulation 2006;113:517-24.

97. Pyeritz RE. Maternal and fetal complications of pregnancy in the Marfan syndrome. Am J Med 1981;71:784-90.

98. van Hagen IM, Roos-Hesselink JW. Aorta pathology and pregnancy. Best Pract Res Clin Obstet Gynaecol 2014;28:537-50.

99. Louhanana G. [The electrical activity of the heart during pregnancy]. Rev Fr Gynecol Obstet 1990;85:369-74.

100. Shotan A, Ostrzega E, Mehra A, Johnson JV, Elkayam U. Incidence of arrhythmias in normal pregnancy and relation to palpitations, dizziness, and syncope. Am J Cardiol 1997;79:1061-4.

101. Ferrero S, Colombo BM, Ragni N. Maternal arrhythmias during pregnancy. Arch Gynecol Obstet 2004;269:244-53.

102. Romem A, Romem Y, Katz M, Battler A. Incidence and characteristics of maternal cardiac arrhythmias during labor. Am J Cardiol 2004;93:931-3.

103. Mason DT, Lee G, Chan MC, DeMaria AN. Arrhythmias in patients with mitral valve prolapse. Types, evaluation, and therapy. Med Clin North Am 1984;68:1039-49.

104. Baedeker W. [Mitral valve prolapse syndrome and arrhythmias]. Herz 1988;13:31825. 


\section{Errata}

Paper I: Reproductive patterns and pregnancy outcomes in women with congenital heart disease - a Swedish population-based study. Acta Obstet Gynecol Scand 2011 Jun;90(6):659-65.

\begin{tabular}{|l|l|l|}
\hline Page/line & Original text & Correction \\
\hline Page 661/Table 2 & $\begin{array}{l}\text { All variables were measured } \\
\text { at the time of the studied } \\
\text { women's births }\end{array}$ & $\begin{array}{l}\text { Parent's educational levels } \\
\text { were measured in 1970 or in } \\
\text { 1985. All other variables } \\
\text { were measured at the time of } \\
\text { the studied women's births }\end{array}$ \\
\hline $\begin{array}{l}\text { Page 663/right } \\
\text { column/line 1-2 }\end{array}$ & $\begin{array}{l}\text { For the newborn child to } \\
\text { receive a diagnosis of CHD } \\
\text { in the NPR }\end{array}$ & $\begin{array}{l}\text { For the newborn child to } \\
\text { receive a diagnosis of CHD } \\
\text { in the MBR }\end{array}$ \\
\hline
\end{tabular}

Paper II: Congenital heart disease in men - birth characteristics and reproduction: a national cohort study. BMC Pregnancy Childbirth. 2014; 14: 187.

\begin{tabular}{|l|l|l|}
\hline Page/line & Original text & Correction \\
\hline $\begin{array}{l}\text { Page 3/left } \\
\text { column/line 24- } \\
25\end{array}$ & $\begin{array}{l}\text { We performed a } \\
\text { multivariable logistic } \\
\text { regression analysis }\end{array}$ & $\begin{array}{l}\text { We performed a multiple } \\
\text { logistic regression analysis }\end{array}$ \\
\hline Page 4/Table 2 & $\begin{array}{l}\text { All variables were measured } \\
\text { at the time of the studied } \\
\text { men's births }\end{array}$ & $\begin{array}{l}\text { Parent's educational levels } \\
\text { were measured in 1985. All } \\
\text { other variables were } \\
\text { measured at the time of the } \\
\text { studied men's births }\end{array}$ \\
\hline
\end{tabular}




\section{Papers}

The articles associated with this thesis have been removed for copyright reasons. For more details about these see:

http://urn.kb.se/resolve? urn:nbn:se:liu:diva-134854 